\title{
Total Synthesis of (+)-Tubelactomicin A (Part 1): Stereoselective Synthesis of the Lower-Half Segment by an Intramolecular Diels-Alder Approach
}

\author{
Toru Motozaki, Kiyoto Sawamura, Akari Suzuki, Keigo Yoshida, Tatsuo Ueki, Aiko Ohara, \\ Ryosuke Munakata, Ken-ichi Takao, and Kin-ichi Tadano* \\ Department of Applied Chemistry, Keio University, Hiyoshi, Kohoku-ku, Yokohama 223-8522, Japan
}

\section{Supporting Information}

\section{Experimental Section}

\begin{abstract}
General
Specific rotations were measured in a $10 \mathrm{~mm}$ cell. ${ }^{1} \mathrm{H}$ NMR spectra were recorded at $300 \mathrm{MHz}$ with tetramethylsilane as an internal standard unless otherwise described. ${ }^{13} \mathrm{C}$ NMR spectra were recorded at 68 $\mathrm{MHz}$ or at $75 \mathrm{MHz}$. All spectra were recorded in the solvent indicated. ${ }^{1} \mathrm{H}$ NMR spectral data are tabulated in the order; multiplicity (s, singlet; d, doublet; t, triplet; q, quartet; m, multiplet), coupling constant, number of protons. High-resolution mass spectra (HRMS) were measured by the EI method $(70 \mathrm{eV})$ unless otherwise noted. Thin-layer chromatography (TLC) was performed with a glass plate coated with Kieselgel 60 F254 (Merck). The crude reaction mixtures and extractive materials were purified by chromatography on silica gel Daisogel IR-60 (Daiso Co., Ltd.) or Wakogel C-300 (Wako Pure Chemical Industries). Unless otherwise described, reactions were carried out at ambient temperature. Combined organic extracts were dried over anhydrous $\mathrm{Na}_{2} \mathrm{SO}_{4}$. Solvents were removed from reaction mixture or combined organic extracts by concentration under reduced pressure using an evaporator with a water bath at $30-40{ }^{\circ} \mathrm{C}$.
\end{abstract}

\section{Diethyl (R)-malate (5) ${ }^{1}$}

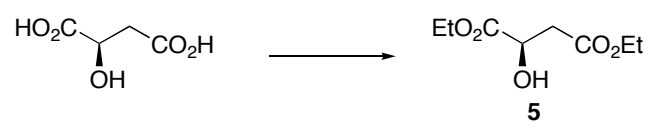

A solution of D-malic acid $(7.47 \mathrm{~g}, 55.7 \mathrm{mmol})$ in $\mathrm{EtOH}(300 \mathrm{~mL})$ was treated with $99.8 \%$ sulfuric acid $(1.4 \mathrm{~mL})$. The mixture was heated at reflux for $13 \mathrm{~h}$, concentrated in vacuo, and purified by column chromatography on silica gel (EtOAc/hexane, 1:4) to provide $9.93 \mathrm{~g}(94 \%)$ of $\mathbf{5}$ as a colorless oil; TLC, $\mathrm{R}_{f} 0.30$ (EtOAc/hexane, $1: 2)$.

\footnotetext{
${ }^{1}$ Wipf, P.; Uto, Y.; Yoshimura, S. Chem. Eur. J. 2002, 8, 1670-1681.
} 


\section{Diethyl (2R,3RS)-3-(prop-2-enyl)malate $(6, c a .8: 1 \text { diastereomeric mixture })^{2}$}

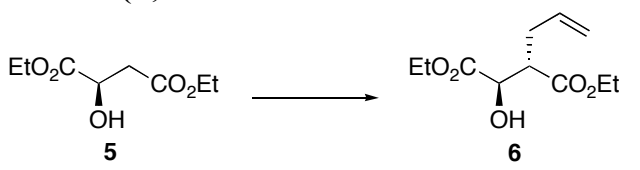

The following reaction was carried out under argon. To a cooled $\left(\square 78^{\circ} \mathrm{C}\right)$, stirred solution of $i-\mathrm{Pr}_{2} \mathrm{NH}(17 \mathrm{~mL}$, $0.12 \mathrm{~mol})$ in THF $(195 \mathrm{~mL}$ ) was added $n$-BuLi $(38 \mathrm{~mL}$ of $2.59 \mathrm{M}$ in $n$-hexane, $97 \mathrm{mmol})$. The mixture was stirred at $-78{ }^{\circ} \mathrm{C}$ for $30 \mathrm{~min}$ and then a solution of $5(9.21 \mathrm{~g}, 48.4 \mathrm{mmol})$ in THF $(6 \mathrm{~mL})$ was added and warmed to $-18{ }^{\circ} \mathrm{C}$ within $30 \mathrm{~min}$. The mixture was cooled to $-78{ }^{\circ} \mathrm{C}$ again and allyl bromide $(11 \mathrm{~mL}, 0.12 \mathrm{~mol})$ was added. The mixture was stirred at $-78{ }^{\circ} \mathrm{C}$ for $2 \mathrm{~h}$ and was warmed to $-5{ }^{\circ} \mathrm{C}$ within $13 \mathrm{~h}$. The reaction mixture was quenched by adding a solution of acetic acid $(12 \mathrm{~mL})$ in $\mathrm{Et}_{2} \mathrm{O}(20 \mathrm{~mL})$ at $-50{ }^{\circ} \mathrm{C}$ and then diluted with $\mathrm{H}_{2} \mathrm{O}(70 \mathrm{~mL})$ and $\mathrm{Et}_{2} \mathrm{O}(500 \mathrm{~mL})$. The separated organic layer was washed with saturated aqueous $\mathrm{NaHCO}_{3}(40 \mathrm{~mL})$ and with saturated aqueous $\mathrm{NaCl}(40 \mathrm{~mL})$. The combined aqueous layers were extracted with $\mathrm{Et}_{2} \mathrm{O}$ (200 mL $\square 2$ ). The organic layer was dried and concentrated in vacuo. The residue was purified by column chromatography on silica gel (EtOAc/hexane, 1:8) to provide $7.73 \mathrm{~g}(69 \%)$ of the inseparable mixture of 6 and its C3-diastereomer (8:1 determined by ${ }^{1} \mathrm{H}$ NMR) as a colorless oil; TLC, $\mathrm{R}_{f} 0.60$ (EtOAc/hexane, 1:2).

(2R,3RS)-3-(Prop-2-enyl)-1,2,4-butanetriol (7, ca. 8:1 diastereomeric mixture) ${ }^{3}$ $(2 R, 4 R, 5 R)-4-H y d r o x y m e t h y l-2-p h e n y l-5-(p r o p-2-e n y l)-1,3-d i o x a n e ~(8)^{3}$

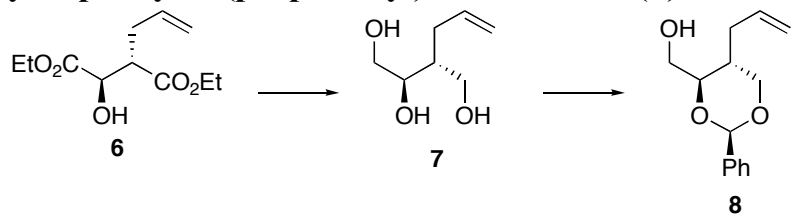

The following reaction was carried out under argon. To a stirred solution of $\mathrm{LiAlH}_{4}(1.90 \mathrm{~g}, 50.1 \mathrm{mmol})$ in THF $(78 \mathrm{~mL})$ was added a solution of $6(5.21 \mathrm{~g}, 22.6 \mathrm{mmol})$ in THF $(78 \mathrm{~mL})$ via addition funnel. The mixture was stirred for $2 \mathrm{~h}$ and then quenched with $\mathrm{AcOH}(4 \mathrm{~mL})$ at $0{ }^{\circ} \mathrm{C}$. Pyridine $(100 \mathrm{~mL})$ and $\mathrm{Ac}_{2} \mathrm{O}(50 \mathrm{~mL})$ was added and the mixture was refluxed overnight. The reaction mixture was cooled to $0{ }^{\circ} \mathrm{C}$ and then diluted with $1 \mathrm{M}$ aqueous $\mathrm{HCl}(200 \mathrm{~mL})$ and extracted with $\mathrm{Et}_{2} \mathrm{O}(100 \mathrm{~mL} \square 3)$. The combined organic layers were washed with saturated aqueous $\mathrm{NaHCO}_{3}(25 \mathrm{~mL} \square 3)$. The organic layer was dried and concentrated with the aid of toluene. The residue was filtered through silica gel to provide crude peracetate. This crude material was used in the next reaction without further purification.

To a solution of the crude peracetate in $\mathrm{MeOH}(120 \mathrm{~mL})$ was added $\mathrm{NaOMe}(45 \mathrm{~mL}$ of $1 \mathrm{M}$ in $\mathrm{MeOH}, 4.5$ mmol). The mixture was refluxed overnight. Then the mixture was neutralized with Amberlite IR-120 and the resin was filtered off. The filtrate was concentrated in vacuo to give crude 7, which was used in the next step without further purification.

The following reaction was carried out under argon. To a solution of crude 7 in $\mathrm{CH}_{2} \mathrm{Cl}_{2}(62 \mathrm{~mL})$ was added $\mathrm{PhCH}(\mathrm{OMe})_{2}(2.7 \mathrm{~mL}, 23 \mathrm{mmol})$ and Amberlyst $15(782 \mathrm{mg}, 25 \mathrm{wt} \%)$. The mixture was stirred overnight and then the resin was filtered off. The filtrate was concentrated in vacuo. The residue was purified by column chromatography on silica gel (EtOAc/hexane, 1:8) to provide $3.52 \mathrm{~g} \mathrm{(67 \%} \mathrm{from} \mathbf{6})$ of $\mathbf{8}$ as a colorless oil; TLC,

\footnotetext{
${ }^{2}$ Seebach, D.; Aebi, J.; Wasmuth, D. Org. Synth., 1985, 63, 109-120.

${ }^{3}$ Morimoto, Y.; Mikami, A.; Kuwabe, S.; Shirahama, H. Tetrahedron: Asymmetry 1996, 7, 3371-3390.
} 
$\mathrm{R}_{f} 0.54$ (EtOAc/hexane, 1:2).

$(2 R, 4 R, 5 R)-4-[(4-M e t h o x y b e n z y l o x y) m e t h y l]-2-p h e n y l-5-(p r o p-2-e n y l)-1,3-d i o x a n e \quad(9)$

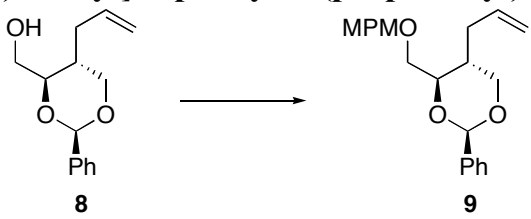

To a cooled $\left(0{ }^{\circ} \mathrm{C}\right)$, stirred solution of $8(8.50 \mathrm{~g}, 36.3 \mathrm{mmol})$ in DMF $(170 \mathrm{~mL})$ were added $\mathrm{NaH}(60 \%$ in oil, $2.18 \mathrm{~g}, 54.4 \mathrm{mmol})$ and 4-methoxybenzyl chloride $(4.9 \mathrm{~mL}, 36 \mathrm{mmol})$. The mixture was stirred for $3.5 \mathrm{~h}$ and quenched with $\mathrm{H}_{2} \mathrm{O}$. This was diluted with $\mathrm{H}_{2} \mathrm{O}(150 \mathrm{~mL})$ and saturated aqueous $\mathrm{NaHCO}_{3}(50 \mathrm{~mL})$ and extracted with $\mathrm{Et}_{2} \mathrm{O}(100 \mathrm{~mL} \square 3)$. The combined organic layers were dried and concentrated with the aid of toluene. The residue was purified by column chromatography on silica gel (toluene/triethylamine, 100:1 then

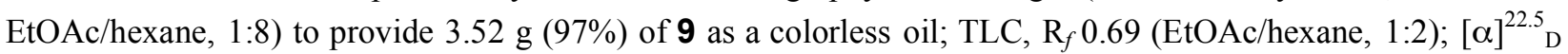
-79.2 (c 2.20, $\left.\mathrm{CHCl}_{3}\right)$; ${ }^{1} \mathrm{H}-\mathrm{NMR}\left(300 \mathrm{MHz}, \mathrm{CDCl}_{3}\right.$ ) $\square$ 1.77-1.87 (m, 1H), 2.05-2.23 (m, 2H), 3.57 (dd, $J=11.2$, $11.2 \mathrm{~Hz}, 1 \mathrm{H}), 3.61-3.79(\mathrm{~m}, 3 \mathrm{H}), 3.80(\mathrm{~s}, 3 \mathrm{H}), 4.22(\mathrm{dd}, J=11.3,4.8 \mathrm{~Hz}, 1 \mathrm{H}), 4.50,4.59(2 \mathrm{~d}, J=11.8 \mathrm{~Hz}$, $1 \mathrm{H} \square 2), 5.00-5.06(\mathrm{~m}, 2 \mathrm{H}), 5.47(\mathrm{~s}, 1 \mathrm{H}), 5.65-5.79(\mathrm{~m}, 1 \mathrm{H}), 6.85-6.90(\mathrm{~m}, 2 \mathrm{H}), 7.26-7.39(\mathrm{~m}, 5 \mathrm{H}), 7.48-7.53(\mathrm{~m}$, $2 \mathrm{H}) ;{ }^{13} \mathrm{C}-\mathrm{NMR}\left(68 \mathrm{MHz}, \mathrm{CDCl}_{3}\right) \square 32.28,34.78,55.20,70.38,71.07,73.06,81.18,101.19,113.69 \square 2,117.00$, $126.16 \square 2,128.14 \square 2,128.72,129.35 \square 2,130.30,134.68,138.39,159.13$; IR (neat) 3060, 3040, 2920, 2360, $1600 \mathrm{~cm}^{\square}$; HRMS calcd for $\mathrm{C}_{22} \mathrm{H}_{26} \mathrm{O}_{4}\left(\mathrm{M}^{+}\right) \mathrm{m} / \mathrm{z} 354.1831$, found 354.1831 .

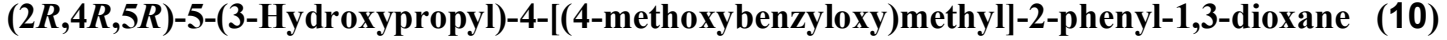

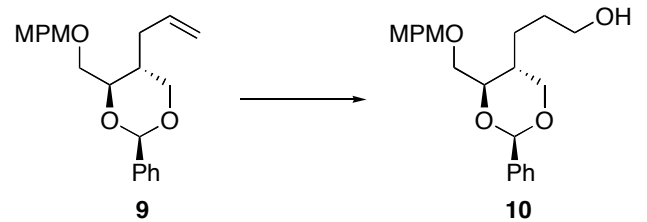

The following reaction was carried out under argon. To a cooled $\left(0{ }^{\circ} \mathrm{C}\right)$, stirred solution of $9(12.5 \mathrm{~g}, 35.2$ mmol) in THF $(250 \mathrm{~mL})$ was added $\mathrm{BH}_{3} \cdot \mathrm{SMe}_{2}$ complex $(1.8 \mathrm{~mL}, 18 \mathrm{mmol})$. The mixture was stirred for $2.5 \mathrm{~h}$ and then $1 \mathrm{M}$ aqueous $\mathrm{NaOH}(93 \mathrm{~mL})$ and $35 \% \mathrm{H}_{2} \mathrm{O}_{2}(32 \mathrm{~mL})$ was added at $0{ }^{\circ} \mathrm{C}$. The mixture was stirred for 1 $\mathrm{h}$ and then quenched with $10 \%$ aqueous $\mathrm{Na}_{2} \mathrm{~S}_{2} \mathrm{O}_{3}(200 \mathrm{~mL})$ at $0{ }^{\circ} \mathrm{C}$. This was extracted with $\mathrm{Et}_{2} \mathrm{O}(150 \mathrm{~mL} \square 3)$. The combined organic layers were dried and concentrated in vacuo. The residue was purified by column chromatography on silica gel (EtOAc/hexane, 2:5) to provide $11.3 \mathrm{~g}(86 \%)$ of 10 as a colorless oil; TLC, $\mathrm{R}_{f}$

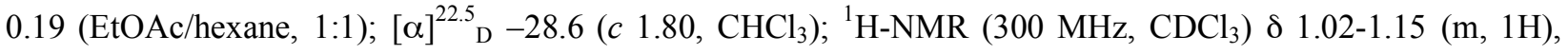
1.39-1.67 (m, 4H), 2.04-2.07 (m, 1H), 3.57 (dd, $J=11.3,11.3 \mathrm{~Hz}, 1 \mathrm{H}), 3.59-3.61(\mathrm{~m}, 2 \mathrm{H}), 3.70-3.75(\mathrm{~m}, 3 \mathrm{H})$, 3.80 (s, 3H), 4.29 (dd, $J=11.3,4.8 \mathrm{~Hz}, 1 \mathrm{H}), 4.49,4.60(2 \mathrm{~d}, J=11.8 \mathrm{~Hz}, 1 \mathrm{H} \square 2), 5.48$ (s, 1H), 6.85-6.90 (m, 2H), 7.26-7.39 (m, 5H), 7.48-7.52 (m, 2H); ${ }^{13} \mathrm{C}-\mathrm{NMR}\left(68 \mathrm{MHz}, \mathrm{CDCl}_{3}\right) \square 23.61,29.28,34.96,55.23,62.49$, $70.41,71.33,73.11,81.58,101.25,113.72 \square 2,126.16 \square 2,128.17 \square 2,128.75,129.44 \square 2,130.25,138.40,159.19$; IR (neat) 3440, 2940, 2860, 2360, 2340, 1620, $1580 \mathrm{~cm}^{\square}$; HRMS calcd for $\mathrm{C}_{22} \mathrm{H}_{28} \mathrm{O}_{5}\left(\mathrm{M}^{+}\right) \mathrm{m} / \mathrm{z} 372.1937$, found 372.1948 . 
(2R,4R,5R)-5-[3-(t-Butyldimethylsilyloxy)propyl]-4-[(4-methoxybenzyloxy)methyl]-2-phenyl-1,3-dioxane

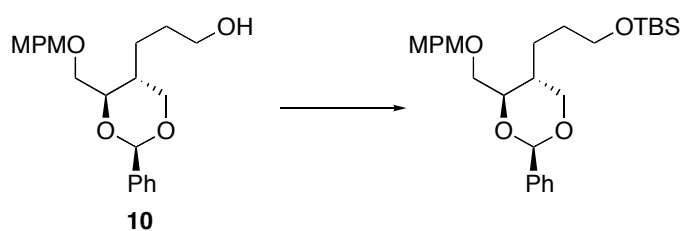

To a cooled $\left(0^{\circ} \mathrm{C}\right)$, stirred solution of $10(10.1 \mathrm{~g}, 27.2 \mathrm{mmol})$ in DMF $(200 \mathrm{~mL})$ were added imidazole $(3.70 \mathrm{~g}$, $54.3 \mathrm{mmol})$ and TBSCl $(4.10 \mathrm{~g}, 27.2 \mathrm{mmol})$. The mixture was stirred for $2 \mathrm{~h}$ and imidazole $(0.76 \mathrm{~g}, 11 \mathrm{mmol})$ and TBSCl $(0.84 \mathrm{~g}, 5.6 \mathrm{mmol})$ were added at $0{ }^{\circ} \mathrm{C}$. The mixture was stirred for $1 \mathrm{~h}$ and then diluted with $\mathrm{H}_{2} \mathrm{O}$ (400 mL). This was extracted with $\mathrm{CH}_{2} \mathrm{Cl}_{2}(200 \mathrm{~mL} \square 2)$. The combined organic layers were dried and concentrated with the aid of toluene. The residue was purified by column chromatography on silica gel (EtOAc/hexane, 1:20) to provide $12.8 \mathrm{~g}(96 \%)$ of the TBS ether as a colorless oil; TLC, $\mathrm{R}_{f} 0.79$ (EtOAc/hexane, 1:2); [ []$^{22.5}{ }_{\mathrm{D}}-25.9$ (c 2.05, $\mathrm{CHCl}_{3}$ ); ${ }^{1} \mathrm{H}-\mathrm{NMR}\left(300 \mathrm{MHz}, \mathrm{CDCl}_{3}\right) \square 0.04$ (s, 6H), 0.89 (s, 9H), 1.01-1.13 (m, $1 \mathrm{H}), 1.38-1.58(\mathrm{~m}, 4 \mathrm{H}), 1.96-2.06(\mathrm{~m}, 1 \mathrm{H}), 3.54-3.76(\mathrm{~m}, 5 \mathrm{H}), 3.65(\mathrm{dd}, J=11.3,11.3 \mathrm{~Hz}, 1 \mathrm{H}), 3.80(\mathrm{~s}, 3 \mathrm{H})$, $4.28(\mathrm{dd}, J=11.3,4.9 \mathrm{~Hz}, 1 \mathrm{H}), 4.51,4.58(2 \mathrm{~d}, J=11.8 \mathrm{~Hz}, 1 \mathrm{H} \square 2), 5.47(\mathrm{~s}, 1 \mathrm{H}), 6.84-6.88(\mathrm{~m}, 2 \mathrm{H}), 7.26-7.39$ (m, 5H), 7.49-7.52 (m, 2H); ${ }^{13} \mathrm{C}-\mathrm{NMR}\left(68 \mathrm{MHz}, \mathrm{CDCl}_{3}\right) \square \square 5.33 \square 2,18.28,23.90,25.92 \square 3,29.54,35.10,55.20$, $62.89,70.59,71.39,73.84,81.69,101.16,113.69 \square 2,126.19 \square 2,128.43 \square 2,128.69,129.32 \square 2,130.29,138.48$, 159.13; IR (neat) 3070, 3040, 2930, 2860, $1620 \mathrm{~cm}^{\square}$; HRMS calcd for $\mathrm{C}_{28} \mathrm{H}_{42} \mathrm{O}_{5} \mathrm{Si}\left(\mathrm{M}^{+}\right) \mathrm{m} / \mathrm{z} 486.2802$, found 486.2800 .

$(2 R, 4 R, 5 R)-5$-[3-(t-Butyldimethylsilyloxy)propyl]-4-hydroxymethyl-2-phenyl-1,3-dioxane (11)

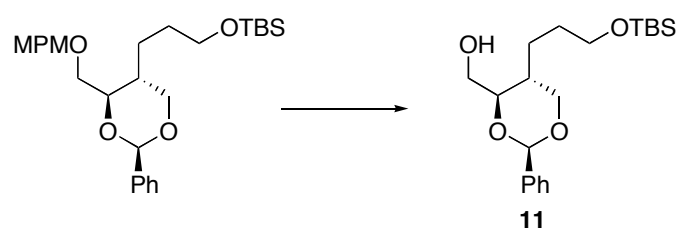

To a cooled $\left(0{ }^{\circ} \mathrm{C}\right)$, stirred solution of the MPM ether $(12.8 \mathrm{~g}, 26.2 \mathrm{mmol})$ in $\mathrm{CH}_{2} \mathrm{Cl}_{2} / \mathrm{H}_{2} \mathrm{O}(15: 1,260 \mathrm{~mL})$ was added DDQ (11.9 g, $52.4 \mathrm{mmol})$. The mixture was stirred for $1.5 \mathrm{~h}$ and then diluted with saturated aqueous $\mathrm{NaHCO}_{3}(260 \mathrm{~mL})$ and $\mathrm{H}_{2} \mathrm{O}(320 \mathrm{~mL})$. This was extracted with $\mathrm{CH}_{2} \mathrm{Cl}_{2}(320 \mathrm{~mL} \square 2)$. The combined organic layers were washed with $\mathrm{H}_{2} \mathrm{O}(400 \mathrm{~mL} \square 3)$. The aqueous layer was reextracted with $\mathrm{CH}_{2} \mathrm{Cl}_{2}(320 \mathrm{~mL})$. The combined organic layers were dried and concentrated in vacuo. The residue was purified by column chromatography on silica gel (toluene then EtOAc/hexane, 1:8 to 1:5) to provide $9.42 \mathrm{~g}(98 \%)$ of 11 as a

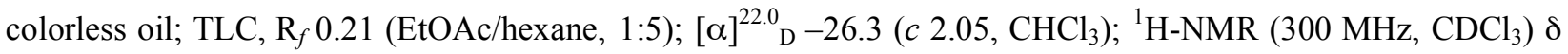
0.05 (s, 6H), 0.90 (s, 9H), 1.39-1.64 (m, 3H), 1.91-2.04 (m, 1H), 2.18 (broad s, 1H), 3.57 (dd, $J=11.3,11.3 \mathrm{~Hz}$, $1 \mathrm{H}), 3.53-3.73(\mathrm{~m}, 4 \mathrm{H}), 3.86-3.89(\mathrm{~m}, 1 \mathrm{H}), 4.29(\mathrm{dd}, J=11.4,4.9 \mathrm{~Hz}, 1 \mathrm{H}), 5.52(\mathrm{~s}, 1 \mathrm{H}), 7.26-7.51(\mathrm{~m}, 5 \mathrm{H})$; ${ }^{13} \mathrm{C}-\mathrm{NMR}\left(68 \mathrm{MHz}, \mathrm{CDCl}_{3}\right) \square \square 5.36 \square 2,18.28,23.78,25.89 \square 3,29.46,34.38,62.72,63.24,71.15,82.16,101.10$, $126.10 \square 2,128.26 \square 2,128.95,138.19$; IR (neat) 3070, 3040, 2950, 2930, 2860, $1620 \mathrm{~cm}^{\square}$; HRMS calcd for $\mathrm{C}_{20} \mathrm{H}_{34} \mathrm{O}_{4} \mathrm{Si}\left(\mathrm{M}^{+}\right) \mathrm{m} / \mathrm{z} 366.2226$, found 366.2228.

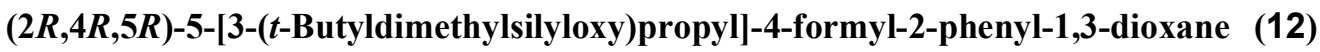




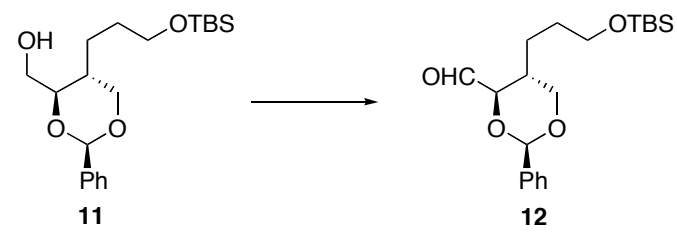

To a cooled $\left(0{ }^{\circ} \mathrm{C}\right)$, stirred solution of $11(2.51 \mathrm{~g}, 6.85 \mathrm{mmol})$ in $\mathrm{CH}_{2} \mathrm{Cl}_{2}(50 \mathrm{~mL})$ was added Dess-Martin periodinane $(3.78 \mathrm{~g}, 8.90 \mathrm{mmol})$. The mixture was stirred for $2 \mathrm{~h}$ and then diluted with saturated aqueous $\mathrm{NaHCO}_{3} / 20 \%$ aqueous $\mathrm{Na}_{2} \mathrm{~S}_{2} \mathrm{O}_{3}(1: 1,80 \mathrm{~mL})$ at $0{ }^{\circ} \mathrm{C}$. The mixture was vigorously stirred for 10 min and then the organic layer was separated. The aqueous layer was extracted with $\mathrm{CH}_{2} \mathrm{Cl}_{2}(50 \mathrm{~mL} \mathrm{~L})$. The combined organic layers were dried and concentrated in vacuo. The residue was purified by column chromatography on silica gel (EtOAc/hexane, 1:5) to provide $2.39 \mathrm{~g}(96 \%)$ of 12 as a colorless oil; TLC, $\mathrm{R}_{f} 0.50$ (EtOAc/hexane, 1:4); $[\square]^{21.0}{ }_{\mathrm{D}}+4.50\left(c \mathrm{1} .95, \mathrm{CHCl}_{3}\right) ;{ }^{1} \mathrm{H}-\mathrm{NMR}\left(300 \mathrm{MHz}, \mathrm{CDCl}_{3}\right) \square 0.05(\mathrm{~s}, 6 \mathrm{H}), 0.90(\mathrm{~s}, 9 \mathrm{H}), 1.10-1.70$ (m, $4 \mathrm{H}), 2.04-2.17(\mathrm{~m}, 1 \mathrm{H}), 3.57-3.67(\mathrm{~m}, 5 \mathrm{H}), 3.97(\mathrm{dd}, J=10.7,2.1 \mathrm{~Hz}, 1 \mathrm{H}), 4.40(\mathrm{dd}, J=11.4,4.8 \mathrm{~Hz}, 1 \mathrm{H})$, $5.56(\mathrm{~s}, 1 \mathrm{H}), 7.38-7.54(\mathrm{~m}, 5 \mathrm{H}), 9.66(\mathrm{~d}, J=2.1 \mathrm{~Hz}, 1 \mathrm{H}) ;{ }^{13} \mathrm{C}-\mathrm{NMR}\left(68 \mathrm{MHz}, \mathrm{CDCl}_{3}\right) \square \square 5.36 \square 2,18.26,22.98$,

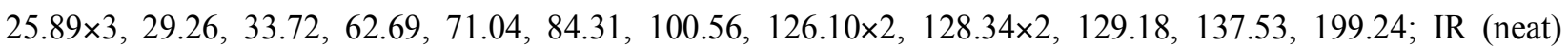
2960, 2930, 2855, $1740 \mathrm{~cm}^{\square}$; HRMS calcd for $\mathrm{C}_{20} \mathrm{H}_{32} \mathrm{O}_{4} \mathrm{Si}\left(\mathrm{M}^{+}\right) \mathrm{m} / \mathrm{z}$ 364.2070, found 364.2073.

\section{Diethyl diiodomethylmethylmalonate ${ }^{4}$}

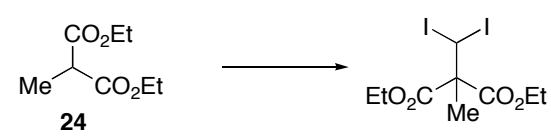

The following reaction was carried out under argon. Diethyl methylmalonate 24 (6.83 g, $39.2 \mathrm{mmol})$ was added to $\mathrm{NaH}(60 \%$ in oil, $1.57 \mathrm{~g}, 39.2 \mathrm{mmol})$ in $\mathrm{Et}_{2} \mathrm{O}(70 \mathrm{~mL})$ during $10 \mathrm{~min}$ with vigorous stirring and the resulting thick mixture was refluxed for $2.5 \mathrm{~h} . \mathrm{CHI}_{3}(15.4 \mathrm{~g}, 39.2 \mathrm{mmol})$ was added in one portion and the mixture refluxed for $21 \mathrm{~h}$. After being cooled to $0{ }^{\circ} \mathrm{C}, 10 \%$ aqueous $\mathrm{HCl}(20 \mathrm{~mL})$ was added and the mixture stirred for $10 \mathrm{~min}$. The organic layer was separated and the aqueous layer was extracted with $\mathrm{Et}_{2} \mathrm{O}(25 \mathrm{~mL} \square 2)$. The combined organic layers were dried and concentrated in vacuo. The residue was diluted with light petroleum $(30 \mathrm{~mL})$ and the precipitated iodoform was removed by filtration. The solvent was removed at reduced pressure and the remaining liquid distilled (b.p. $156-157{ }^{\circ} \mathrm{C}$ at $4.5 \mathrm{mmHg}$ ) to provide the title compound $(11.1 \mathrm{~g}, 65 \%)$ as a pale pink oil.

\section{(E)-3-Iodo-2-methylprop-2-enoic acid ${ }^{4}$}

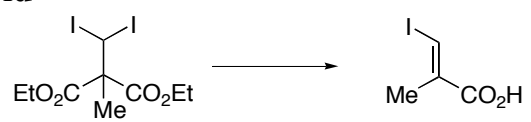

A solution of diethyl diiodomethylmethylmalonate $(11.7 \mathrm{~g}, 26.6 \mathrm{mmol})$ and $\mathrm{KOH}(4.48 \mathrm{~g}, 79.8 \mathrm{mmol})$ in EtOH $/ \mathrm{H}_{2} \mathrm{O}(3: 1,117 \mathrm{~mL})$ was refluxed for $23 \mathrm{~h}$. After being cooled to ambient temperature, the mixture was concentrated in vacuo. The residue was redissolved in $10 \%$ aqueous $\mathrm{K}_{2} \mathrm{CO}_{3}(70 \mathrm{~mL})$ and the mixture was washed with $\mathrm{CH}_{2} \mathrm{Cl}_{2}\left(22 \mathrm{~mL} \mathrm{\square}\right.$ ). The basic solution was acidified with $12 \mathrm{M} \mathrm{HCl}$ and extracted with $\mathrm{CH}_{2} \mathrm{Cl}_{2}$ (25 mL 75 ). The combined organic layers were dried and concentrated in vacuo. The residue was purified by

\footnotetext{
${ }^{4}$ Baker, R.; Castro, J. L. J. Chem. Soc., Perkin Trans. 1 1990, 47-65.
} 
column chromatography on silica gel (EtOAc/hexane, 1:4, 1\% AcOH) to provide $4.66 \mathrm{~g}(87 \%)$ of the carboxylic acid as a colorless oil.

\section{(E)-3-Iodo-2-methylprop-2-enol (25) ${ }^{4}$}

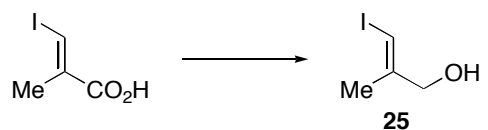

To a cooled $\left(0{ }^{\circ} \mathrm{C}\right)$, stirred solution of the carboxylic acid $(4.66 \mathrm{~g}, 22.0 \mathrm{mmol})$ in THF $(47 \mathrm{~mL})$ was added $\mathrm{LiAlH}_{4}(0.834 \mathrm{~g}, 22.0 \mathrm{mmol})$. The mixture was stirred for $5.5 \mathrm{~h}$ and additional $\mathrm{LiAlH}_{4}(83.4 \mathrm{mg}, 2.20 \mathrm{mmol})$ was added and the mixture was stirred for $30 \mathrm{~min}$. The reaction mixture was cooled to $0{ }^{\circ} \mathrm{C}$ and quenched with saturated aqueous $\mathrm{Na}_{2} \mathrm{SO}_{4}(1.2 \mathrm{~mL})$. $\mathrm{Et}_{2} \mathrm{O}(30 \mathrm{~mL})$ was added and the mixture was poured into $2 \mathrm{M}$ aqueous $\mathrm{H}_{2} \mathrm{SO}_{4}(45 \mathrm{~mL})$, then the organic layer was separated and the aqueous layer was extracted with $\mathrm{CH}_{2} \mathrm{Cl}_{2}(15 \mathrm{~mL}$ $\square 2$ ). The combined organic layers were concentrated in vacuo and the remaining oil dissolved in $\mathrm{CH}_{2} \mathrm{Cl}_{2}$ (30 $\mathrm{mL})$ and washed with $10 \%$ aqueous $\mathrm{K}_{2} \mathrm{CO}_{3}(15 \mathrm{~mL})$. The basic aqueous layer was reextracted with $\mathrm{CH}_{2} \mathrm{Cl}_{2}(15$ $\mathrm{mL} \mathrm{C}^{2}$ ). The combined organic layers were dried and concentrated in vacuo. The residue was purified by column chromatography on silica gel (EtOAc/hexane, $\left.1: 5 \_1: 1\right)$ to provide $2.69 \mathrm{~g}(62 \%)$ of 25 as a colorless oil.

\section{(E)-2-Methyl-5-(trimethylsilyl)pent-2-en-4-yn-1-ol (26) ${ }^{5}$}

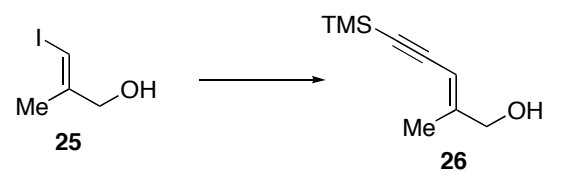

The following reaction was carried out under argon. To a stirred solution of 25 (727 $\mathrm{mg}, 3.67 \mathrm{mmol})$ in degassed pyrrolidine $(15 \mathrm{~mL})$ was added trimethylsilylacetylene $(1.0 \mathrm{~mL}, 7.34 \mathrm{mmol}), \mathrm{Pd}\left(\mathrm{PPh}_{3}\right)_{4}(212 \mathrm{mg}$, $0.184 \mathrm{mmol}), \mathrm{CuI}(69.9 \mathrm{mg}, 0.367 \mathrm{mmol})$. The mixture was stirred for $1.5 \mathrm{~h}$, and then diluted with saturated aqueous $\mathrm{NH}_{4} \mathrm{Cl}(30 \mathrm{~mL})$ at $0{ }^{\circ} \mathrm{C}$ and extracted with $\mathrm{Et}_{2} \mathrm{O}(15 \mathrm{~mL} \square 3)$. The combined organic layers were dried and concentrated with the aid of toluene. The residue was purified by column chromatography on silica gel (EtOAc/hexane, 1:10) to provide $525 \mathrm{mg}(85 \%)$ of $\mathbf{2 6}$ as a colorless oil.

\section{(E)-1-Bromo-2-methyl-5-(trimethylsilyl)pent-2-en-4-yne}

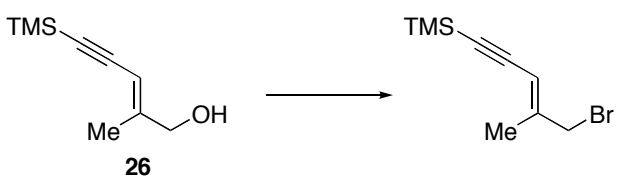

To a cooled $\left(0{ }^{\circ} \mathrm{C}\right)$, stirred solution of $26(1.67 \mathrm{~g}, 9.92 \mathrm{mmol})$ in $\mathrm{CH}_{2} \mathrm{Cl}_{2}(33 \mathrm{~mL})$ were added $\mathrm{CBr}_{4}(4.28 \mathrm{~g}$, $12.9 \mathrm{mmol})$ and $\mathrm{PPh}_{3}(3.90 \mathrm{~g}, 14.9 \mathrm{mmol})$. The mixture was stirred for $15 \mathrm{~min}$ at $0{ }^{\circ} \mathrm{C}$ and then concentrated in

5 de Lera, A. R.; Iglesias, B.; Rodriguez, J.; Alvarez, R.; Lopez, S.; Villanueva, X.; Padros, E. J. Am. Chem. Soc. 1995, 117, 8220-8231. 
vacuo. The residue was purified by column chromatography on silica gel (EtOAc/hexane, 1:100) to provide $2.22 \mathrm{~g}(97 \%)$ of the bromide as a colorless oil; TLC, $\mathrm{R}_{f} 0.63$ (EtOAc/hexane, 1:10); ${ }^{1} \mathrm{H}-\mathrm{NMR}$ (300 MHz, $\left.\mathrm{CDCl}_{3}\right) \square 0.20(\mathrm{~s}, 9 \mathrm{H}), 2.03(\mathrm{~d}, J=0.9 \mathrm{~Hz}, 3 \mathrm{H}), 3.98(\mathrm{~s}, 2 \mathrm{H}), 5.66(\mathrm{~s}, 1 \mathrm{H}) ;{ }^{13} \mathrm{C}-\mathrm{NMR}\left(68 \mathrm{MHz}, \mathrm{CDCl}_{3}\right)$ Q $\square 0.09 \square 3,17.82,37.92,100.70,101.88,110.29,147.49$; IR (neat) 2960, $2130 \mathrm{~cm}^{\square}$; HRMS calcd for $\mathrm{C}_{9} \mathrm{H}_{15}{ }^{81} \mathrm{BrSi}\left(\mathrm{M}^{+}\right) \mathrm{m} / \mathrm{z} 232.0106$, found 232.0109.

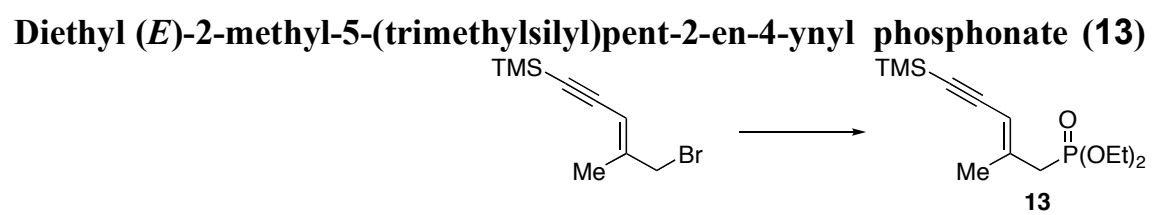

The following reaction was carried out under argon. The bromide $(2.00 \mathrm{~g}, 8.65 \mathrm{mmol})$ was dissolved in $\mathrm{P}(\mathrm{OEt})_{3}$ $(2.2 \mathrm{~mL}, 13 \mathrm{mmol})$ and the mixture was refluxed for $30 \mathrm{~min}$. After being cooled to ambient temperature, the mixture was concentrated with the aid of toluene. The residue was purified by column chromatography on silica gel (EtOAc/hexane, 3:1) to provide $2.11 \mathrm{~g} \mathrm{(85 \% )}$ of 13 as a colorless oil; TLC, $\mathrm{R}_{f} 0.40$ (EtOAc/hexane, 2:1); ${ }^{1} \mathrm{H}-\mathrm{NMR}\left(300 \mathrm{MHz}, \mathrm{CDCl}_{3}\right) \square 0.19(\mathrm{~s}, 9 \mathrm{H}), 1.32(\mathrm{t}, J=7.1 \mathrm{~Hz}, 6 \mathrm{H}), 2.05(\mathrm{dd}, J=4.0,1.1 \mathrm{~Hz}, 3 \mathrm{H}), 2.63$ $(\mathrm{dd}, J=23.1,0.6 \mathrm{~Hz}, 2 \mathrm{H}), 4.09,4.12(2 \mathrm{q}, J=7.1 \mathrm{~Hz}, 2 \mathrm{H} \square 2), 5.43(\mathrm{dd}, J=5.8,1.1 \mathrm{~Hz}, 1 \mathrm{H}) ;{ }^{13} \mathrm{C}-\mathrm{NMR}(68$ $\left.\mathrm{MHz}, \mathrm{CDCl}_{3}\right) \square \square 0.06 \square 3,16.34 \square 2\left(J_{\mathrm{PC}}=5.8 \mathrm{~Hz}\right), 20.65\left(J_{\mathrm{PC}}=3.9 \mathrm{~Hz}\right), 36.15\left(J_{\mathrm{PC}}=138 \mathrm{~Hz}\right), 61.97 \square 2\left(J_{\mathrm{PC}}=\right.$ $7.8 \mathrm{~Hz}), 98.37\left(J_{\mathrm{PC}}=3.9 \mathrm{~Hz}\right), 102.33\left(J_{\mathrm{PC}}=5.9 \mathrm{~Hz}\right), 109.61\left(J_{\mathrm{PC}}=13.6 \mathrm{~Hz}\right), 143.35\left(J_{\mathrm{PC}}=11.7 \mathrm{~Hz}\right) ; \mathrm{IR}$ (neat) 2980, 2960, 2900, 2360, 2340, 2170, $2130 \mathrm{~cm}^{\square}$; HRMS calcd for $\mathrm{C}_{13} \mathrm{H}_{25} \mathrm{O}_{3} \mathrm{PSi}\left(\mathrm{M}^{+}\right) \mathrm{m} / \mathrm{z} 288.1311$, found 288.1307 .

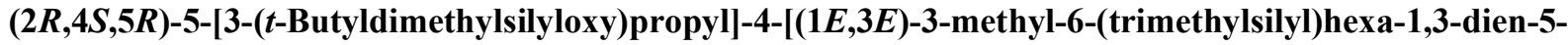 ynyl]-2-phenyl-1,3-dioxane (14, ca. 93:5:2 geometric mixture)}

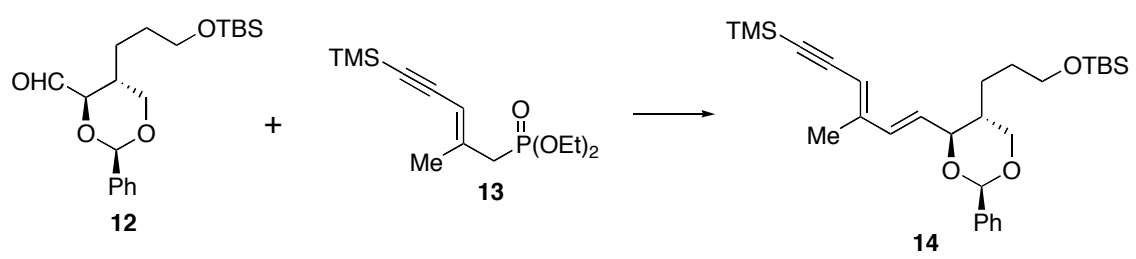

The following reaction was carried out under argon. To a cooled $\left(\square 78^{\circ} \mathrm{C}\right)$, stirred solution of the phosphonate $13(3.03 \mathrm{~g}, 10.5 \mathrm{mmol})$ in THF $(60 \mathrm{~mL})$ was added dropwise LiHMDS (10.5 mL of $1.0 \mathrm{M}$ solution in $n$-hexane, $10.5 \mathrm{mmol})$. The mixture was stirred at $\square 78{ }^{\circ} \mathrm{C}$ for $60 \mathrm{~min}$ and then a solution of 12 (2.93 g, $\left.8.04 \mathrm{mmol}\right)$ in THF $(5 \mathrm{~mL})$ was added. After being stirred at $\square 78^{\circ} \mathrm{C}$ for $20 \mathrm{~min}$, HMPA $(1.8 \mathrm{~mL}, 10.5 \mathrm{mmol})$ was added. The mixture was warmed to $15{ }^{\circ} \mathrm{C}$ within $4.5 \mathrm{~h}$, and quenched with saturated aqueous $\mathrm{NH}_{4} \mathrm{Cl}(50 \mathrm{~mL})$ at $0{ }^{\circ} \mathrm{C}$. This was diluted with $\mathrm{H}_{2} \mathrm{O}(20 \mathrm{~mL})$ and extracted with $\mathrm{Et}_{2} \mathrm{O}(40 \mathrm{~mL} \square 3)$. The combined organic layers were washed with saturated aqueous $\mathrm{NaCl}(10 \mathrm{~mL})$ and $\mathrm{H}_{2} \mathrm{O}(10 \mathrm{~mL})$. The organic layer was dried and concentrated in vacuo. The residue was purified by column chromatography on silica gel $\left(\mathrm{Et}_{2} \mathrm{O} /\right.$ hexane, $\left.1: 30\right)$ to provide $3.00 \mathrm{~g}(75 \%)$ of 14 as a colorless oil. ${ }^{1} \mathrm{H}$ NMR spectroscopy showed the product to contain approximately $5 \%$ of the unwanted $(1 E, 3 Z)$ isomer and $2 \%$ of $(1 Z, 3 E)$ isomer. Chromatographic separation of the double-bond isomers proved not possible at this stage, and the isomeric mixture was carried through subsequent steps for separation at a later stage. The oil exhibited the following properties; TLC, $\mathrm{R}_{f} 0.69$ (EtOAc/hexane, 1:4); $[\square]^{23.0}{ }_{\mathrm{D}} \square 65.9$ ( $c$ $\left.1.55, \mathrm{CHCl}_{3}\right) ;{ }^{1} \mathrm{H}-\mathrm{NMR}\left(300 \mathrm{MHz}, \mathrm{CDCl}_{3}\right) \square 0.04(\mathrm{~s}, 6 \mathrm{H}), 0.21(\mathrm{~s}, 9 \mathrm{H}), 0.89$ (s, 9H), 0.99-1.10 (m, 1H), 1.40- 
$1.59(\mathrm{~m}, 3 \mathrm{H}), 1.80-1.90(\mathrm{~m}, 1 \mathrm{H}), 2.01(\mathrm{~d}, J=0.4 \mathrm{~Hz}, 3 \mathrm{H}), 3.54-3.63(\mathrm{~m}, 3 \mathrm{H}), 4.03(\mathrm{dd}, J=9.7,7.8 \mathrm{~Hz}, 1 \mathrm{H})$, $4.31(\mathrm{dd}, J=11.4,4.6 \mathrm{~Hz}, 1 \mathrm{H}), 5.51(\mathrm{~s}, 1 \mathrm{H}), 5.53(\mathrm{~s}, 1 \mathrm{H}), 5.83(\mathrm{dd}, J=15.6,7.8 \mathrm{~Hz}, 1 \mathrm{H}), 6.35(\mathrm{~d}, J=15.6 \mathrm{~Hz}$, $1 \mathrm{H}), 7.29-7.39(\mathrm{~m}, 3 \mathrm{H}), 7.48-7.51(\mathrm{~m}, 2 \mathrm{H}) ;{ }^{13} \mathrm{C}-\mathrm{NMR}\left(68 \mathrm{MHz}, \mathrm{CDCl}_{3}\right) \square \square 5.30 \square 2, \square 0.002 \square 3,15.23,18.28$, $24.10,25.89 \square 3,29.57,38.90,62.80,71.62,83.45,101.16,102.14,103.26,111.10,126.19 \square 2,128.29 \square 2,128.86$, 129.38, 135.92, 138.31, 147.26; IR (neat) 2960, 2920, 2895, 2855, 2130, 1950, 1880, 1815, 1740, 1640, 1585, 1500, 1470, $1455 \mathrm{~cm}^{\square}$; HRMS calcd for $\mathrm{C}_{29} \mathrm{H}_{46} \mathrm{O}_{3} \mathrm{Si}_{2}\left(\mathrm{M}^{+}\right) \mathrm{m} / \mathrm{z}$ 498.2986, found 498.2988.

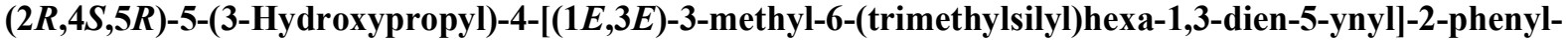
1,3-dioxane (15, ca. 93:5:2 geometric mixture)
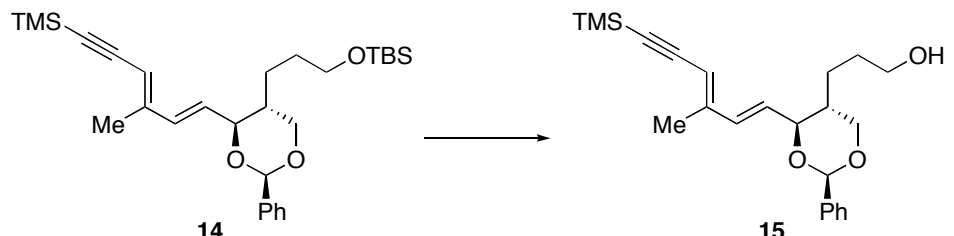

Compound $14(3.00 \mathrm{~g}, 6.01 \mathrm{mmol})$ was dissolved in $\mathrm{AcOH} / \mathrm{THF} / \mathrm{H}_{2} \mathrm{O}(3: 2: 1,60 \mathrm{~mL})$. The mixture was stirred for $22 \mathrm{~h}$ and then concentrated with the aid of $\mathrm{EtOH}$ and toluene. The residue was purified by column chromatography on silica gel (EtOAc/hexane, 1:1) to provide $2.24 \mathrm{~g}(97 \%)$ of the inseparable mixture of 15 and its geometrical isomers derived from Horner-Emmons reaction as a colorless solid. The solid exhibited the

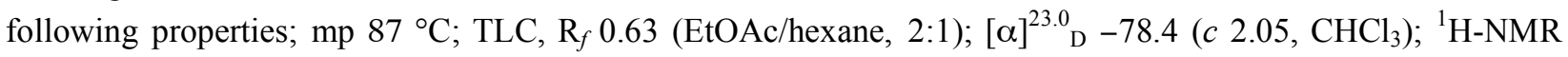
$\left(300 \mathrm{MHz}, \mathrm{CDCl}_{3}\right) \square 0.21(\mathrm{~s}, 9 \mathrm{H}), 1.00-1.13(\mathrm{~m}, 1 \mathrm{H}), 1.35-1.66(\mathrm{~m}, 3 \mathrm{H}), 1.81-1.94(\mathrm{~m}, 1 \mathrm{H}), 2.02(\mathrm{~d}, J=0.9 \mathrm{~Hz}$, $3 \mathrm{H}), 3.57-3.65$ (m, 3H), 4.04 (dd, $J=9.8,7.8 \mathrm{~Hz}, 1 \mathrm{H}), 4.33$ (dd, $J=11.3,4.7 \mathrm{~Hz}, 1 \mathrm{H}), 5.52(\mathrm{~s}, 1 \mathrm{H}), 5.54$ (s, $1 \mathrm{H}), 5.83(\mathrm{dd}, J=15.6,7.8 \mathrm{~Hz}, 1 \mathrm{H}), 6.36(\mathrm{~d}, J=15.6 \mathrm{~Hz}, 1 \mathrm{H}), 7.26-7.39(\mathrm{~m}, 3 \mathrm{H}), 7.47-7.51(\mathrm{~m}, 2 \mathrm{H}) ;{ }^{13} \mathrm{C}-$ NMR (68 MHz, $\left.\mathrm{CDCl}_{3}\right) \square \square 0.03 \square 3,15.26,24.07,29.46,38.90,62.69,71.47,83.39,101.16,102.31,103.15$,

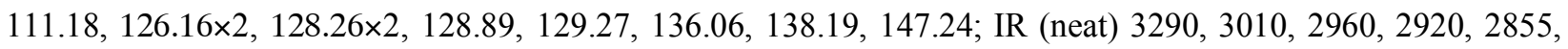
$2125 \mathrm{~cm}^{\square}$; HRMS calcd for $\mathrm{C}_{23} \mathrm{H}_{32} \mathrm{O}_{3} \mathrm{Si}\left(\mathrm{M}^{+}\right) \mathrm{m} / \mathrm{z} 384.2121$, found 384.2123 .

$(2 R, 4 S, 5 R)-5-(2-F o r m y l e t h y l)-4-[(1 E, 3 E)-3-m e t h y l-6-(t r i m e t h y l s i l y l) h e x a-1,3-d i e n-5-y n y l]-2-p h e n y l-1,3-$ dioxane (ca. 93:5:2 geometric mixture)
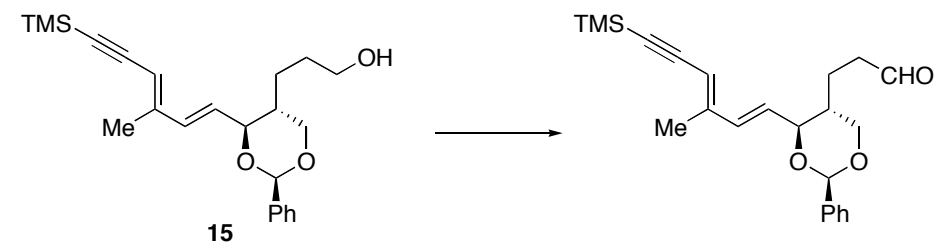

To a cooled $\left(0{ }^{\circ} \mathrm{C}\right)$, stirred solution of $15(202 \mathrm{mg}, 0.525 \mathrm{mmol})$ in $\mathrm{CH}_{2} \mathrm{Cl}_{2}(4 \mathrm{~mL})$ was added Dess-Martin periodinane $(334 \mathrm{mg}, 0.787 \mathrm{mmol}$ ). The mixture was stirred for $1 \mathrm{~h}$ and then diluted with saturated aqueous $\mathrm{NaHCO}_{3} / 20 \%$ aqueous $\mathrm{Na}_{2} \mathrm{~S}_{2} \mathrm{O}_{3}(1: 1,12 \mathrm{~mL})$ at $0{ }^{\circ} \mathrm{C}$. The mixture was vigorously stirred for 10 min and then the organic layer was separated. The aqueous layer was extracted with $\mathrm{CH}_{2} \mathrm{Cl}_{2}(6 \mathrm{~mL} \square 3)$. The combined organic layers were dried and concentrated in vacuo. The residue was purified by column chromatography on silica gel (EtOAc/hexane, 1:4) to provide $198 \mathrm{mg}(99 \%)$ of the inseparable mixture of the aldehyde and its geometrical isomers derived from Horner-Emmons reaction as a colorless solid. The solid exhibited the

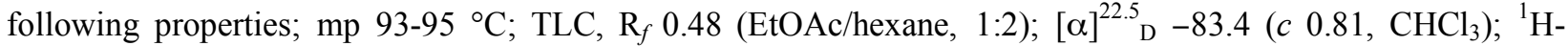


NMR (300 MHz, CDCl $\left.)_{3}\right) \square 0.21(\mathrm{~s}, 9 \mathrm{H}), 1.23-1.36(\mathrm{~m}, 1 \mathrm{H}), 1.62-1.74(\mathrm{~m}, 1 \mathrm{H}), 1.79-1.92(\mathrm{~m}, 1 \mathrm{H}), 2.03(\mathrm{~s}, 3 \mathrm{H})$, $2.47(\mathrm{t}, J=7.6 \mathrm{~Hz}, 2 \mathrm{H}), 3.59$ (dd, $J=11.3,11.3 \mathrm{~Hz}, 1 \mathrm{H}), 4.05(\mathrm{dd}, J=9.4,7.9 \mathrm{~Hz}, 1 \mathrm{H}), 4.27$ (dd, $J=11.3,4.7$ $\mathrm{Hz}, 1 \mathrm{H}), 5.53(2 \mathrm{~s}, 1 \mathrm{H} \square 2), 5.82(\mathrm{dd}, J=15.6,7.9 \mathrm{~Hz}, 1 \mathrm{H}), 6.38(\mathrm{~d}, J=15.6 \mathrm{~Hz}, 1 \mathrm{H}), 7.33-7.39$ (m, 3H), 7.477.50 (m, 2H), 9.75 (s, 1H); ${ }^{13} \mathrm{C}-\mathrm{NMR}\left(68 \mathrm{MHz}, \mathrm{CDCl}_{3}\right) \square \square 0.03 \square 3,15.26,19.84,38.61,41.03,71.13,83.25$, $101.22,102.54,103.09,111.59,126.16 \square 2,128.32 \square 2,128.89,128.98,136.49,138.05,147.01,200.94$; IR (neat) 2960, 2920, 2850, 2740, 2130, 1730, $1715 \mathrm{~cm}^{\square}$; HRMS calcd for $\mathrm{C}_{23} \mathrm{H}_{30} \mathrm{O}_{3} \mathrm{Si}\left(\mathrm{M}^{+}\right) \mathrm{m} / \mathrm{z} \mathrm{382.1964}$, found 382.1966.

$(2 R, 4 S, 5 R)-5-[(3 E)-4-($ Ethoxycarbonyl)pent-3-enyl]-4-[(1E,3E)-3-methyl-6-(trimethylsilyl)hexa-1,3-dien5-ynyl]-2-phenyl-1,3-dioxane (16, ca. 93:5:2 geometric mixture)

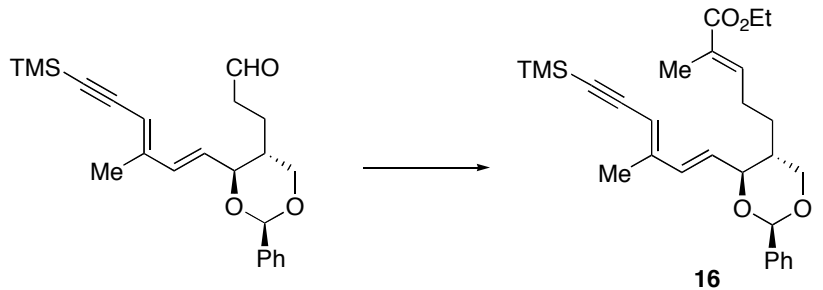

The following reaction was carried out under argon. To a stirred solution of the aldehyde ( $887 \mathrm{mg}, 2.32 \mathrm{mmol})$ in benzene $(17 \mathrm{~mL})$ was added $\mathrm{Ph}_{3} \mathrm{P}=\mathrm{C}(\mathrm{Me}) \mathrm{CO}_{2} \mathrm{Et}(1.26 \mathrm{~g}, 3.48 \mathrm{mmol})$. The mixture was stirred for $5 \mathrm{~h}$ and then concentrated in vacuo. The residue was purified by column chromatography on silica gel (EtOAc/hexane, 1:20) to provide $986 \mathrm{mg}$ (91\%) of the inseparable mixture of $\mathbf{1 6}$ and its geometrical isomers derived from Horner-Emmons reaction as a colorless oil. The oil exhibited the following properties; TLC, $\mathrm{R}_{f} 0.72$

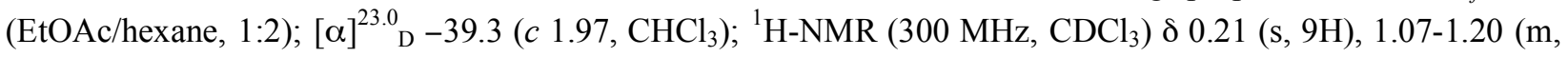
$1 \mathrm{H}), 1.30(\mathrm{t}, J=7.2 \mathrm{~Hz}, 3 \mathrm{H}), 1.42-1.57(\mathrm{~m}, 1 \mathrm{H}), 1.82(\mathrm{~s}, 3 \mathrm{H}), 1.86-1.94(\mathrm{~m}, 1 \mathrm{H}), 2.02(\mathrm{~s}, 1 \mathrm{H}), 2.08-2.23(\mathrm{~m}$, 2H), 3.62 (dd, $J=11.3,11.3 \mathrm{~Hz}, 1 \mathrm{H}), 4.02$ (dd, $J=9.7,7.9 \mathrm{~Hz}, 1 \mathrm{H}), 4.19$ (q, $J=7.2 \mathrm{~Hz}, 2 \mathrm{H}), 4.32$ (dd, $J=11.3$, $4.7 \mathrm{~Hz}, 1 \mathrm{H}), 5.53(\mathrm{~s}, 1 \mathrm{H}), 5.54(\mathrm{~s}, 1 \mathrm{H}), 5.82(\mathrm{dd}, J=15.6,7.9 \mathrm{~Hz}, 1 \mathrm{H}), 6.36(\mathrm{~d}, J=15.6 \mathrm{~Hz}, 1 \mathrm{H}), 6.65(\mathrm{dt}, J=$ 1.3, 7.4 Hz, 1H), 7.30-7.40 (m, 3H), 7.46-7.53 (m, 2H); ${ }^{13} \mathrm{C}-\mathrm{NMR}\left(68 \mathrm{MHz}, \mathrm{CDCl}_{3}\right) \square \square 0.06 \square 3,12.41,14.25$, $15.23,25.63,26.69,38.73,60.50,71.27,83.31,101.16,102.43,103.09,111.38,126.13 \square 2,128.26 \square 2,128.55$, 128.89, 129.06, 136.26, 138.11, 140.53, 147.06, 167.88; IR (neat) 2960, 2920, 2850, 2130, 1715, 1650, 1455 $\mathrm{cm}^{\square^{1}}$; HRMS calcd for $\mathrm{C}_{28} \mathrm{H}_{38} \mathrm{O}_{4} \mathrm{Si}\left(\mathrm{M}^{+}\right) \mathrm{m} / \mathrm{z} 466.2539$, found 466.2535 .

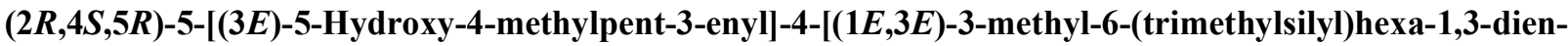 5-ynyl]-2-phenyl-1,3-dioxane (ca. 93:5:2 geometric mixture)}
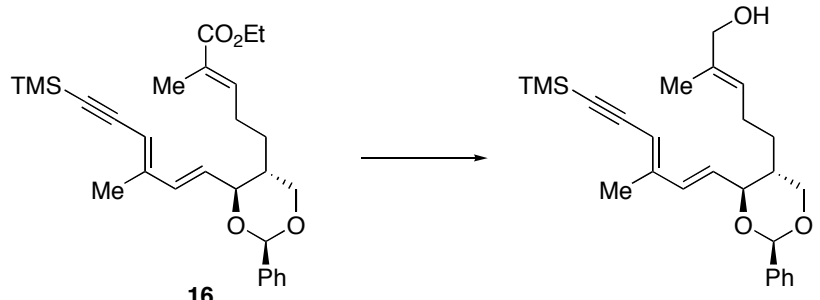

The following reaction was carried out under argon. To a cooled $\left(\square 78^{\circ} \mathrm{C}\right)$, stirred solution of 16 (632 $\mathrm{mg}, 1.35$ mmol) in $\mathrm{CH}_{2} \mathrm{Cl}_{2}(13 \mathrm{~mL})$ was added DIBAL-H (3.4 mL of $1.01 \mathrm{M}$ solution in toluene, $\left.3.4 \mathrm{mmol}\right)$. The mixture was stirred at $\square 78^{\circ} \mathrm{C}$ for 30 min and then quenched with $\mathrm{H}_{2} \mathrm{O}(5 \mathrm{~mL})$. This was diluted with aqueous solution 
$(20 \mathrm{~mL})$ of potassium sodium $(+)$-tartrate tetrahydrate $(2.90 \mathrm{~g})$ and warmed to ambient temperature. The mixture was stirred vigorously for $2 \mathrm{~h}$ and then the organic layer was separated. The aqueous layer was extracted with $\mathrm{CH}_{2} \mathrm{Cl}_{2}(15 \mathrm{~mL} \square 3)$. The combined organic layers were dried and concentrated in vacuo. The residue was purified by column chromatography on silica gel (EtOAc/hexane, 1:8) to provide $549 \mathrm{mg}(95 \%)$ of the inseparable mixture of the allylic alcohol and its geometrical isomers derived from Horner-Emmons reaction as a colorless oil. The oil exhibited the following properties; TLC, $\mathrm{R}_{f} 0.34$ (EtOAc/hexane, 1:2); $\left.[\square]^{23.0} \square 47.3(c) 2.00, \mathrm{CHCl}_{3}\right) ;{ }^{1} \mathrm{H}-\mathrm{NMR}\left(300 \mathrm{MHz}, \mathrm{CDCl}_{3}\right) \square 0.21(\mathrm{~s}, 9 \mathrm{H}), 0.99-1.12(\mathrm{~m}, 1 \mathrm{H}), 1.33-1.45$ (m, $1 \mathrm{H}), 1.65(\mathrm{~s}, 3 \mathrm{H}), 1.81-1.92(\mathrm{~m}, 1 \mathrm{H}), 1.97-2.10(\mathrm{~m}, 2 \mathrm{H}), 2.02(\mathrm{~d}, J=0.9 \mathrm{~Hz}, 3 \mathrm{H}), 3.61(\mathrm{dd}, J=11.3,11.3 \mathrm{~Hz}$, 1H), 3.99 (s, 2H), 4.03 (dd, $J=9.6,7.8 \mathrm{~Hz}, 1 \mathrm{H}), 4.32$ (dd, $J=11.3,4.7 \mathrm{~Hz}, 1 \mathrm{H}), 5.33$ (dt, $J=1.3,7.1 \mathrm{~Hz}, 1 \mathrm{H}$ ), $5.52(\mathrm{~s}, 1 \mathrm{H}), 5.53(\mathrm{~s}, 1 \mathrm{H}), 5.82(\mathrm{dd}, J=15.6,7.8 \mathrm{~Hz}, 1 \mathrm{H}), 6.35$ (d, $J=15.6 \mathrm{~Hz}, 1 \mathrm{H}), 7.29-7.39$ (m, 3H), 7.477.51 (m, 2H); ${ }^{13} \mathrm{C}-\mathrm{NMR}\left(68 \mathrm{MHz}, \mathrm{CDCl}_{3}\right) \square \square 0.06 \square 3,13.59,15.20,24.45,27.50,38.61,68.48,71.36,83.34$,

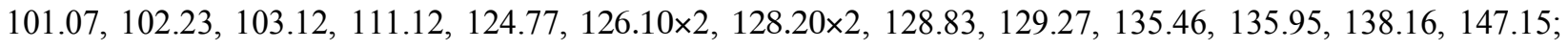
IR (neat) 3410, 2960, 2920, 2860, 2130, $1455 \mathrm{~cm}^{\square}$; HRMS calcd for $\mathrm{C}_{26} \mathrm{H}_{36} \mathrm{O}_{3} \mathrm{Si}\left(\mathrm{M}^{+}\right) \mathrm{m} / \mathrm{z} 424.2434$, found 424.2430 .

$(2 R, 4 S, 5 R)-5-[(3 E)-4-F o r m y l p e n t-3-e n y l]-4-[(1 E, 3 E)-3-m e t h y l-6-(t r i m e t h y l s i l y l) h e x a-1,3-d i e n-5-y n y l]-2-$ phenyl-1,3-dioxane $(4, c a .93: 5: 2$ geometric mixture)
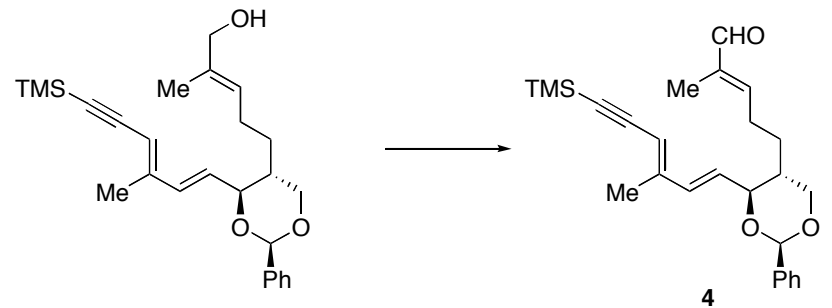

To a cooled $\left(0{ }^{\circ} \mathrm{C}\right)$, stirred solution of the allylic alcohol $(160 \mathrm{mg}, 0.377 \mathrm{mmol})$ in $\mathrm{CH}_{2} \mathrm{Cl}_{2}(3.4 \mathrm{~mL})$ was added Dess-Martin periodinane $(192 \mathrm{mg}, 0.452 \mathrm{mmol})$. The mixture was stirred for $30 \mathrm{~min}$ and then diluted with saturated aqueous $\mathrm{NaHCO}_{3} / 20 \%$ aqueous $\mathrm{Na}_{2} \mathrm{~S}_{2} \mathrm{O}_{3}(1: 1,10 \mathrm{~mL})$ at $0{ }^{\circ} \mathrm{C}$. The mixture was vigorously stirred for $5 \mathrm{~min}$ and then the organic layer was separated. The aqueous layer was extracted with $\mathrm{CH}_{2} \mathrm{Cl}_{2}(7.5 \mathrm{~mL} \square 3)$. The combined organic layers were dried and concentrated in vacuo. The residue was purified by column chromatography on silica gel (EtOAc/hexane, 1:8) to provide $161 \mathrm{mg}(96 \%)$ of the inseparable mixture of 4 and its geometrical isomers derived from Horner-Emmons reaction as a colorless oil. The oil exhibited the following properties; TLC, $\mathrm{R}_{f} 0.52$ (EtOAc/hexane, 1:2); $\left.[\square]\right]_{\mathrm{D}}^{22.0} \mathrm{\square} 40.4$ (c 1.02, $\mathrm{CHCl}_{3}$ ); ${ }^{1} \mathrm{H}-\mathrm{NMR}(300 \mathrm{MHz}$, $\left.\mathrm{CDCl}_{3}\right) \square 0.21(\mathrm{~s}, 9 \mathrm{H}), 1.13-1.28(\mathrm{~m}, 1 \mathrm{H}), 1.47-1.57(\mathrm{~m}, 1 \mathrm{H}), 1.74(\mathrm{~s}, 3 \mathrm{H}), 1.84-1.98(\mathrm{~m}, 1 \mathrm{H}), 2.03(\mathrm{~d}, J=0.7$ $\mathrm{Hz}, 3 \mathrm{H}), 2.26-2.42(\mathrm{~m}, 2 \mathrm{H}), 3.64(\mathrm{dd}, J=11.3,11.3 \mathrm{~Hz}, 1 \mathrm{H}), 4.06$ (dd, $J=9.6,7.9 \mathrm{~Hz}, 1 \mathrm{H}), 4.34$ (dd, $J=11.3$, $4.7 \mathrm{~Hz}, 1 \mathrm{H}), 5.53(\mathrm{~s}, 1 \mathrm{H}), 5.55(\mathrm{~s}, 1 \mathrm{H}), 5.82(\mathrm{dd}, J=15.6,7.9 \mathrm{~Hz}, 1 \mathrm{H}), 6.35-6.41(\mathrm{~m}, 1 \mathrm{H}), 6.37$ (d, $J=15.6 \mathrm{~Hz}$, 1H), 7.31-7.40 (m, 3H), 7.46-7.51 (m, 2H), $9.40(\mathrm{~s}, 1 \mathrm{H}) ;{ }^{13} \mathrm{C}-\mathrm{NMR}\left(68 \mathrm{MHz}, \mathrm{CDCl}_{3}\right) \square \square 0.03 \square 3,9.30,15.26$,

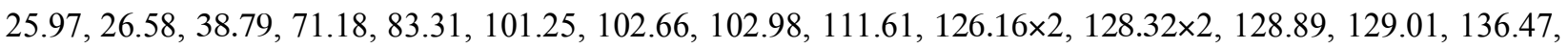
138.02, 139.83, 146.95, 152.79, 194.98; IR (neat) 2960, 2920, 2850, 2130, 1690, 1640, $1450 \mathrm{~cm}^{\square}$; HRMS calcd for $\mathrm{C}_{26} \mathrm{H}_{34} \mathrm{O}_{3} \mathrm{Si}\left(\mathrm{M}^{+}\right) \mathrm{m} / \mathrm{z}$ 422.2277, found 422.2272.

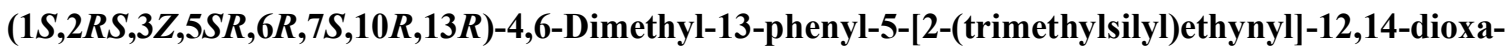
tricyclo $\left[8.4 .0 .0^{2,7}\right]$ tetradec-3-ene-6-carbaldehyde (17-endo/exo, ca. 8:1 diastereomeric mixture) 


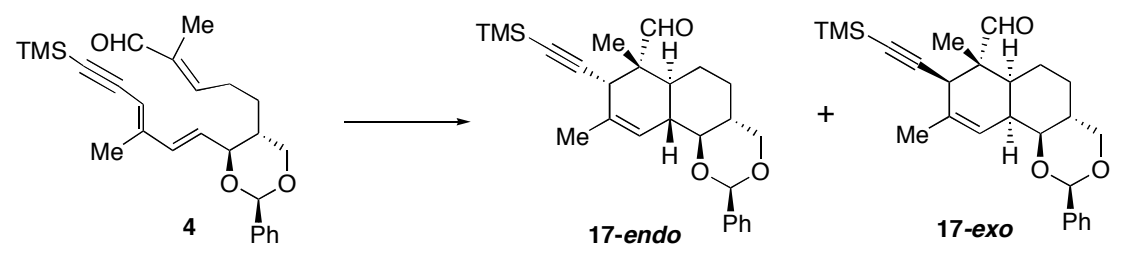

The following reaction was carried out under argon. Compound 4 (96.6 $\mathrm{mg}, 0.229 \mathrm{mmol}$ ) was dissolved in degassed toluene $(2.3 \mathrm{~mL})$ and a crystal of BHT was added. The solution was heated to $80{ }^{\circ} \mathrm{C}$ for $24 \mathrm{~h}$. After being cooled to ambient temperature, the solution was concentrated in vacuo. The residue was purified by column chromatography on silica gel (EtOAc/hexane, 1:30) to provide $89.4 \mathrm{mg}$ (93\%) of 17-endo and its diastereomeric isomer as an amorphous solid. ${ }^{1} \mathrm{H}$ NMR spectroscopy showed the product to contain approximately $11 \%$ of the unwanted exo-cycloadduct 17-exo. Chromatographic separation of the isomer proved difficult at this stage, and the isomeric mixture was carried through subsequent steps for separation at a later stage. In a small-scale experiment, analytical sample of 17-endo was obtained through careful separation of the products by column chromatography on silica gel (EtOAc/hexane, 1:30) as an amorphous solid; TLC, $\mathrm{R}_{f}$

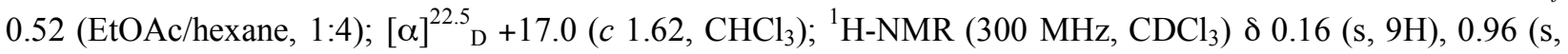
$3 \mathrm{H}), 1.12-1.25(\mathrm{~m}, 2 \mathrm{H}), 1.50-1.53(\mathrm{~m}, 1 \mathrm{H}), 1.60-1.68(\mathrm{~m}, 1 \mathrm{H}), 1.82(\mathrm{~s}, 3 \mathrm{H}), 1.82-1.92(\mathrm{~m}, 1 \mathrm{H}), 2.06-2.10(\mathrm{~m}$, 2H), $2.63(\mathrm{~s}, 1 \mathrm{H}), 3.39(\mathrm{dd}, J=9.7,9.7 \mathrm{~Hz}, 1 \mathrm{H}), 3.64(\mathrm{dd}, J=11.1,11.1 \mathrm{~Hz}, 1 \mathrm{H}), 4.13(\mathrm{dd}, J=11.1,4.3 \mathrm{~Hz}$, $1 \mathrm{H}), 5.59(\mathrm{~s}, 1 \mathrm{H}), 5.79(\mathrm{~s}, 1 \mathrm{H}), 7.34-7.41(\mathrm{~m}, 3 \mathrm{H}), 7.50-7.54(\mathrm{~m}, 2 \mathrm{H}), 9.85(\mathrm{~s}, 1 \mathrm{H}) ;{ }^{13} \mathrm{C}-\mathrm{NMR}\left(68 \mathrm{MHz}, \mathrm{CDCl}_{3}\right)$ $\square \square 0.03 \square 3,12.55,21.77,25.34,25.40,37.09,41.09 \square 2,41.18,48.32,71.64,83.42,90.33,101.51,103.26$,

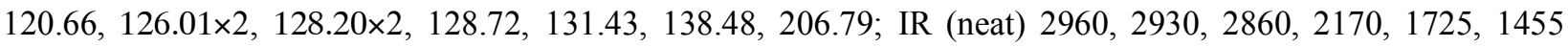
$\mathrm{cm}^{\square}$; HRMS calcd for $\mathrm{C}_{26} \mathrm{H}_{34} \mathrm{O}_{3} \mathrm{Si}\left(\mathrm{M}^{+}\right) \mathrm{m} / \mathrm{z}$ 422.2277, found 422.2281 .

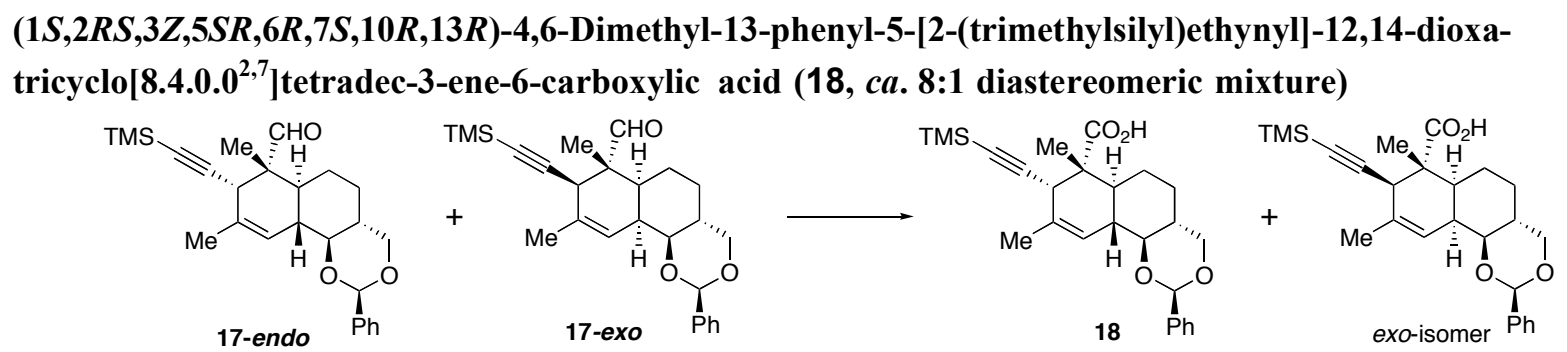

To a cooled $\left(0{ }^{\circ} \mathrm{C}\right)$, stirred solution of 17-endo/exo (122 mg, $0.289 \mathrm{mmol}$; $c$. 8:1 diastereomeric mixture) in $t$ - $\mathrm{BuOH} / \mathrm{H}_{2} \mathrm{O}(5: 1,4 \mathrm{~mL})$ were added 2-methyl-2-butene $(0.15 \mathrm{~mL}, 1.5 \mathrm{mmol}), \mathrm{NaH}_{2} \mathrm{PO}_{4}(52.0 \mathrm{mg}, 0.434$ $\mathrm{mmol})$ and $\mathrm{NaClO}_{2}(52.3 \mathrm{mg}, 0.578 \mathrm{mmol})$. The mixture was stirred for $5.5 \mathrm{~h}$ and then diluted with saturated aqueous $\mathrm{NH}_{4} \mathrm{Cl}(12 \mathrm{~mL})$. This was extracted with $\mathrm{CH}_{2} \mathrm{Cl}_{2}(6 \mathrm{~mL} \square 3)$. The combined organic layers were dried and concentrated in vacuo. The residue was purified by column chromatography on silica gel (EtOAc/hexane, $1: 10$ _ 1:5) to provide $117 \mathrm{mg}(93 \%)$ of $\mathbf{1 8}$ and its diastereomeric isomer as an amorphous solid. Chromatographic separation of the isomer proved difficult at this stage, and the isomeric mixture was carried through subsequent steps for separation at a later stage. In a small-scale experiment, analytical sample of 18 (endo-isomer) was obtained through careful separation of the products by column chromatography on silica gel (EtOAc/hexane, 1:10) as an amorphous solid; TLC, $\mathrm{R}_{f} 0.45$ (EtOAc/hexane, 1:2); $[\square]_{\mathrm{D}}^{21.5}+23.3$ (c 1.29, $\mathrm{CHCl}_{3}$ ); ${ }^{1} \mathrm{H}-\mathrm{NMR}\left(300 \mathrm{MHz}, \mathrm{CDCl}_{3}\right) \square 0.13$ (s, 9H), 1.13-1.20 (m, 2H), 1.19 (s, 3H), 1.62-1.70 (m, 1H), 1.84 $(\mathrm{s}, 3 \mathrm{H}), 1.84-1.88(\mathrm{~m}, 1 \mathrm{H}), 1.92-2.06(\mathrm{~m}, 2 \mathrm{H}), 2.08-2.17(\mathrm{~m}, 1 \mathrm{H}), 2.85(\mathrm{~s}, 1 \mathrm{H}), 3.36(\mathrm{dd}, J=9.5,9.5 \mathrm{~Hz}, 1 \mathrm{H})$, $3.64(\mathrm{dd}, J=11.0,11.0 \mathrm{~Hz}, 1 \mathrm{H}), 4.13(\mathrm{dd}, J=11.0,4.1 \mathrm{~Hz}, 1 \mathrm{H}), 5.59(\mathrm{~s}, 1 \mathrm{H}), 5.76(\mathrm{~s}, 1 \mathrm{H}), 7.32-7.41$ (m, 3H), 
7.52-7.54 (m, 2H); ${ }^{13} \mathrm{C}-\mathrm{NMR}\left(68 \mathrm{MHz}, \mathrm{CDCl}_{3}\right) \square \square 0.06 \square 3,16.04,22.55,25.48,26.23,37.89,41.55,42.30$, $43.77,49.21,71.82,83.68,88.14,101.48,104.73,120.25,126.04 \square 2,128.23 \square 2,128.69,130.94,138.60$, 181.13; IR (neat) 2950, 2855, 2660, 2170, 1715, 1695, 1680, 1460, $1455 \mathrm{~cm}^{\square}$; HRMS calcd for $\mathrm{C}_{26} \mathrm{H}_{34} \mathrm{O}_{4} \mathrm{Si}$ $\left(\mathrm{M}^{+}\right) \mathrm{m} / \mathrm{z}$ 438.2226, found 438.2216.

\section{$(1 S, 2 R, 3 Z, 5 S, 6 R, 7 S, 10 R, 13 R)-5$-Ethynyl-4,6-dimethyl-13-phenyl-12,14-dioxatricyclo[8.4.0.0 $\left.{ }^{2,7}\right]$ tetradec-3-} ene-6-carboxylic acid (19)

$(1 S, 2 S, 3 Z, 5 R, 6 R, 7 S, 10 R, 13 R)-4,6$-Dimethyl-13-phenyl-5-[2-(trimethylsilyl)ethynyl]-12,14-dioxatricyclo$\left[\right.$ 8.4.0.0 ${ }^{2,7}$ ]tetradec-3-ene-6-carboxylic acid (exo-isomer of 18)
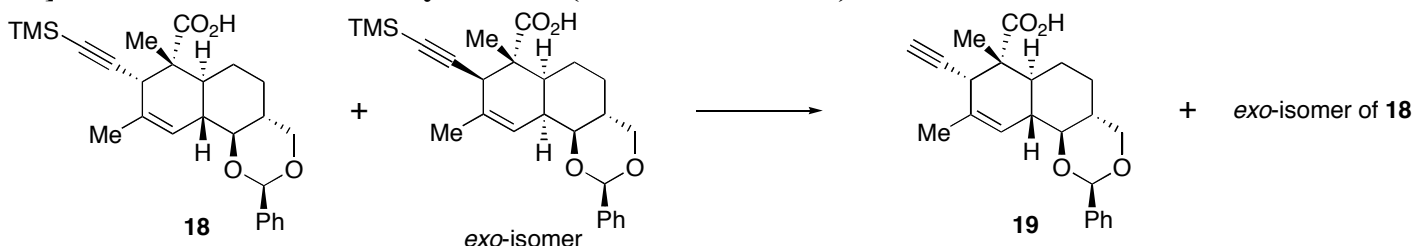

To a cooled $\left(0{ }^{\circ} \mathrm{C}\right)$, stirred solution of $18(504 \mathrm{mg}, 1.15 \mathrm{mmol}$; $c a .8: 1$ diastereomeric mixture $)$ in THF $(15 \mathrm{~mL})$ was added $n-\mathrm{Bu}_{4} \mathrm{NF}(1.2 \mathrm{~mL}$ of $1.0 \mathrm{M}$ solution in THF, $1.2 \mathrm{mmol})$. The mixture was stirred for $1 \mathrm{~h}$, and then diluted with saturated aqueous $\mathrm{NH}_{4} \mathrm{Cl}(30 \mathrm{~mL})$. This was extracted with $\mathrm{CH}_{2} \mathrm{Cl}_{2}(20 \mathrm{~mL} \square 3)$. The combined organic layers were dried and concentrated in vacuo. The residue was purified by column chromatography on silica gel (EtOAc/hexane, 1:5 to 1:1) to provide $345 \mathrm{mg}(89 \%)$ of 19 as a colorless solid and $46.0 \mathrm{mg}(10 \%)$ of the recovered exo-isomer of $\mathbf{1 8}$ as a colorless oil.

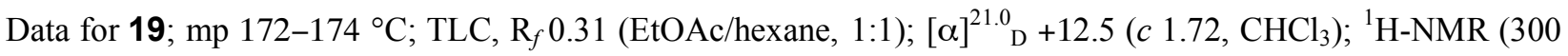
$\left.\mathrm{MHz}, \mathrm{CDCl}_{3}\right) \square 1.14-1.28(\mathrm{~m}, 2 \mathrm{H}), 1.22(\mathrm{~s}, 3 \mathrm{H}), 1.56-1.70(\mathrm{~m}, 1 \mathrm{H}), 1.80-1.90(\mathrm{~m}, 1 \mathrm{H}), 1.86(\mathrm{~s}, 3 \mathrm{H}), 1.95-2.10$ $(\mathrm{m}, 2 \mathrm{H}), 2.14-2.20(\mathrm{~m}, 1 \mathrm{H}), 2.20(\mathrm{~d}, J=2.4 \mathrm{~Hz}, 1 \mathrm{H}), 2.86(\mathrm{~s}, 1 \mathrm{H}), 3.36(\mathrm{dd}, J=9.5,9.5 \mathrm{~Hz}, 1 \mathrm{H}), 3.62(\mathrm{dd}, J=$ 11.0, 11.0 Hz, 1H), $4.13(\mathrm{dd}, J=11.0,4.1 \mathrm{~Hz}, 1 \mathrm{H}), 5.56(\mathrm{~s}, 1 \mathrm{H}), 5.79(\mathrm{~s}, 1 \mathrm{H}), 7.32-7.41(\mathrm{~m}, 3 \mathrm{H}), 7.51-7.53(\mathrm{~m}$, 2H); ${ }^{13} \mathrm{C}-\mathrm{NMR}\left(75 \mathrm{MHz}, \mathrm{CDCl}_{3}\right.$ ) $\square$ 15.97, 22.42, 25.40, 26.09, 37.95, 41.52, 42.32, 42.42, 48.81, 71.82, 71.85, $82.72,83.65,101.48,120.59,126.02 \square 2,128.19 \square 2,128.69,130.69,138.54,180.45$; IR (KBr) 3305, 2930, 2850, 2660, 1735, 1715, 1690, 1680, 1460, $1455 \mathrm{~cm}^{\square}$; HRMS calcd for $\mathrm{C}_{23} \mathrm{H}_{26} \mathrm{O}_{4}\left(\mathrm{M}^{+}\right) \mathrm{m} / \mathrm{z} 366.1831$, found 366.1831 .

Data for the exo-isomer of 18; TLC, $\mathrm{R}_{f} 0.43$ (EtOAc/hexane, 1:1); [ []$^{21.0}{ }_{\mathrm{D}} \square 48.9$ (c 2.07, $\mathrm{CHCl}_{3}$ ); ${ }^{1} \mathrm{H}-\mathrm{NMR}$ $\left(300 \mathrm{MHz}, \mathrm{CDCl}_{3}\right) \square 0.14(\mathrm{~s}, 9 \mathrm{H}), 0.80-0.98(\mathrm{~m}, 1 \mathrm{H}), 1.48(\mathrm{~s}, 3 \mathrm{H}), 1.48-1.66(\mathrm{~m}, 2 \mathrm{H}), 1.77-1.90$ (m, 2H), 1.87 (s, 3H), 2.15 (ddd, $J=12.9,4.1,4.1 \mathrm{~Hz}, 1 \mathrm{H}), 2.67$ (broad s, 1H), 3.52 (dd, $J=11.1,11.1 \mathrm{~Hz}, 1 \mathrm{H}), 3.57$ (dd, $J=$ 10.8, $4.5 \mathrm{~Hz}, 1 \mathrm{H}), 3.58(\mathrm{~s}, 1 \mathrm{H}), 4.11(\mathrm{dd}, J=11.1,4.5 \mathrm{~Hz}, 1 \mathrm{H}), 5.52(\mathrm{~s}, 1 \mathrm{H}), 5.62(\mathrm{~s}, 1 \mathrm{H}), 7.31-7.37(\mathrm{~m}, 3 \mathrm{H})$, 7.46-7.49 (m, 2H); ${ }^{13} \mathrm{C}-\mathrm{NMR}\left(68 \mathrm{MHz}, \mathrm{CDCl}_{3}\right) \square \square 0.09 \square 3,21.34,22.23,22.46,25.40,34.90,37.72,38.44$, $40.34,48.09,71.93,82.44,88.72,101.68,105.85,119.62,126.19 \square 2,128.20 \square 2,128.78,132.72,138.45$, 182.94; IR (neat) 2960, 2940, 2855, 2650, 2170, 1730, 1700, 1695, 1460, $1455 \mathrm{~cm}^{\square}$; HRMS calcd for $\mathrm{C}_{26} \mathrm{H}_{34} \mathrm{O}_{4} \mathrm{Si}\left(\mathrm{M}^{+}\right) \mathrm{m} / \mathrm{z}$ 438.2226, found 438.2229.

$(1 R, 2 S, 4 \mathrm{a} R, 5 S, 6 R, 8 \mathrm{a} S)$-2-Ethynyl-5-hydroxy-6-hydroxymethyl-1,3-dimethyl-1,2,4a,5,6,7,8,8a-octahydronaphthalene-1-carboxylic acid (20)

2-(Trimethylsilyl)ethoxymethyl $(1 R, 2 S, 4 \mathrm{a} R, 5 S, 6 R, 8 \mathrm{a} S)$-2-ethynyl-5-hydroxy-6-hydroxymethyl-1,3dimethyl-1,2,4a,5,6,7,8,8a-octahydronaphthalene-1-carboxylate (21) 


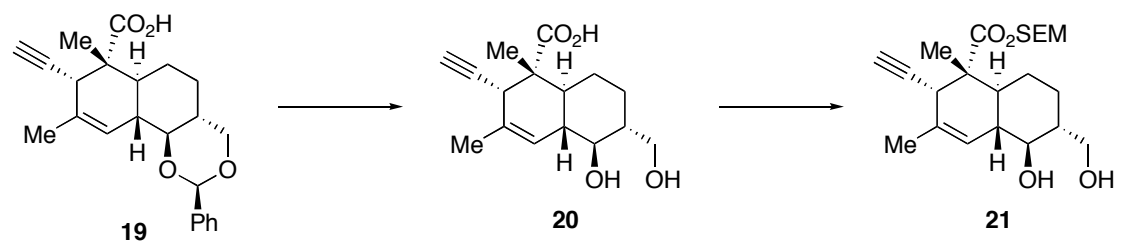

Compound 19 (232 mg, $0.633 \mathrm{mmol})$ was dissolved in $80 \%$ aqueous $\mathrm{AcOH}(20 \mathrm{~mL})$. The mixture was heated to $50{ }^{\circ} \mathrm{C}$ for $5 \mathrm{~h}$ and then concentrated with the aid of EtOH and toluene to give the crude 20 , which was used in the next step without further purification. Analytical sample of $\mathbf{2 0}$ was obtained by column chromatography on silica gel (EtOAc/hexane, 2:1, 1\% AcOH) as a colorless solid in a small-scale experiment.

The following reaction was carried out under argon. To a cooled $\left(0^{\circ} \mathrm{C}\right)$, stirred solution of the crude material 20 obtained above in THF $(4 \mathrm{~mL})$ were added $\mathrm{Et}_{3} \mathrm{~N}(0.18 \mathrm{~mL}, 1.3 \mathrm{mmol})$ and SEMCl $(0.11 \mathrm{~mL}, 0.63 \mathrm{mmol})$. The mixture was stirred $0{ }^{\circ} \mathrm{C}$ for $3 \mathrm{~h}$ and then diluted with saturated aqueous $\mathrm{NH}_{4} \mathrm{Cl}(14 \mathrm{~mL})$. This was extracted with $\mathrm{CH}_{2} \mathrm{Cl}_{2}(7 \mathrm{~mL} \square 3)$. The combined organic layers were dried and concentrated in vacuo. The residue was purified by column chromatography on silica gel (EtOAc/hexane, 1:3) to provide $195 \mathrm{mg}(75 \%, 2$ steps) of $\mathbf{2 1}$ as a colorless oil.

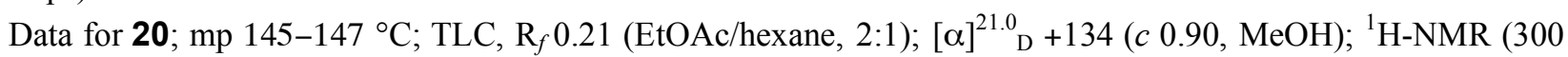
$\mathrm{MHz}$, acetone- $\left.d_{6}\right) \square 0.98-1.16(\mathrm{~m}, 1 \mathrm{H}), 1.12(\mathrm{~s}, 3 \mathrm{H}), 1.53(\mathrm{~m}, 1 \mathrm{H}), 1.66-1.78(\mathrm{~m}, 3 \mathrm{H}), 1.79(\mathrm{~s}, 3 \mathrm{H}), 2.01(\mathrm{~m}$, 1H), $2.08(\mathrm{~m}, 1 \mathrm{H}), 2.49$ (d, $J=2.4 \mathrm{~Hz}, 1 \mathrm{H}), 2.80$ (broad s, 1H), 3.17 (dd, $J=9.4,9.4 \mathrm{~Hz}, 1 \mathrm{H}), 3.64(\mathrm{~d}, J=5.6$ $\mathrm{Hz}, 2 \mathrm{H}), 5.80(\mathrm{~s}, 1 \mathrm{H}) ;{ }^{13} \mathrm{C}-\mathrm{NMR}\left(75 \mathrm{MHz}\right.$, acetone- $\left.d_{6}\right) \mathrm{D} 16.66,22.82,27.11,27.87,38.46,43.08,46.44,47.95$, 48.86, 67.13, 72.76, 77.18, 84.24, 122.98, 131.09, 175.80; IR (KBr) 3370, 3300, 2930, 2885, 2630, 1720, 1705, $1455 \mathrm{~cm}^{\square}$; HRMS calcd for $\mathrm{C}_{16} \mathrm{H}_{22} \mathrm{O}_{4}\left(\mathrm{M}^{+}\right) \mathrm{m} / \mathrm{z} 278.1518$, found 278.1515 .

Data for 21; TLC, $\mathrm{R}_{f} 0.24$ (EtOAc/hexane, 1:1); $[\square]^{20.0} \mathrm{D}+95.3\left(\right.$ c $\left.0.96, \mathrm{CHCl}_{3}\right) ;{ }^{1} \mathrm{H}-\mathrm{NMR}\left(300 \mathrm{MHz}, \mathrm{CDCl}_{3}\right) \square$ $0.03(\mathrm{~s}, 9 \mathrm{H}), 0.97(\mathrm{t}, J=8.4 \mathrm{~Hz}, 2 \mathrm{H}), 1.07-1.20(\mathrm{~m}, 2 \mathrm{H}), 1.19(\mathrm{~s}, 3 \mathrm{H}), 1.67-1.76(\mathrm{~m}, 2 \mathrm{H}), 1.76-1.90(\mathrm{~m}, 2 \mathrm{H})$, $1.85(\mathrm{~s}, 3 \mathrm{H}), 2.08(\mathrm{~m}, 1 \mathrm{H}), 2.14(\mathrm{~d}, J=2.4 \mathrm{~Hz}, 1 \mathrm{H}), 2.84($ broad s, $1 \mathrm{H}), 3.39(\mathrm{dd}, J=9.0,9.0 \mathrm{~Hz}, 1 \mathrm{H}), 3.64-$ $3.76(\mathrm{~m}, 3 \mathrm{H}), 3.78(\mathrm{dd}, J=10.2,3.7 \mathrm{~Hz}, 1 \mathrm{H}), 5.31,5.35(2 \mathrm{~d}, J=6.1 \mathrm{~Hz}, 1 \mathrm{H} \square 2), 5.78(\mathrm{~s}, 1 \mathrm{H}) ;{ }^{13} \mathrm{C}-\mathrm{NMR}(68$ $\left.\mathrm{MHz}, \mathrm{CDCl}_{3}\right) \square \square 1.44 \square 3,16.04,18.00,22.55,26.17,26.55,37.29,42.30,45.18,46.27,48.75,67.87,68.62$, 71.50, 78.41, 82.99, 89.53, 121.06, 130.97, 174.07; IR (neat) 3310, 3285, 3050, 3020, 2890, 2110, 1730, 1715, $1455 \mathrm{~cm}^{\square}$; HRMS calcd for $\mathrm{C}_{22} \mathrm{H}_{36} \mathrm{O}_{5} \mathrm{Si}\left(\mathrm{M}^{+}\right) \mathrm{m} / \mathrm{z} 408.2332$, found 408.2328 .

\section{2-(Trimethylsilyl)ethoxymethyl $(1 R, 2 S, 4 \mathrm{a} R, 5 S, 6 R, 8 \mathrm{a} S)$-2-ethynyl-5-hydroxy-1,3-dimethyl-6-tosyloxy- methyl-1,2,4a,5,6,7,8,8a-octahydronaphthalene-1-carboxylate $(22)$}

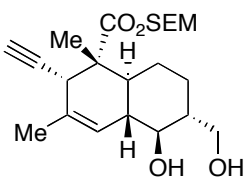

21

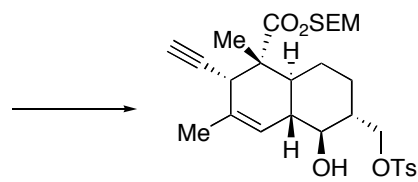

22

To a cooled $\left(0^{\circ} \mathrm{C}\right)$, stirred solution of $21(89.6 \mathrm{mg}, 0.219 \mathrm{mmol})$ in $\mathrm{CH}_{2} \mathrm{Cl}_{2}(2 \mathrm{~mL})$ were added $\mathrm{Et}_{3} \mathrm{~N}(0.10 \mathrm{~mL}$, $0.66 \mathrm{mmol}), \mathrm{TsCl}(62.7 \mathrm{mg}, 0.329 \mathrm{mmol})$ and DMAP $(2.7 \mathrm{mg}, 22 \square \mathrm{mol})$. The mixture was stirred for $2.5 \mathrm{~h}$ and then the mixture was diluted with saturated aqueous $\mathrm{NaHCO}_{3}(5 \mathrm{~mL})$ and $\mathrm{Et}_{2} \mathrm{O}(10 \mathrm{~mL})$. The organic layer was separated and washed with saturated aqueous $\mathrm{NaHCO}_{3}(5 \mathrm{~mL} \square 2)$. The organic layer was dried and concentrated in vacuo. The residue was purified by column chromatography on silica gel (EtOAc/hexane, 1:4) to provide $123 \mathrm{mg}$ (quant.) of 22 as a colorless oil; TLC, $\mathrm{R}_{f} 0.69$ (EtOAc/hexane, 1:1); $[\square]^{21.0}{ }_{\mathrm{D}}+78.0(c 1.01$, 
$\mathrm{CHCl}_{3}$ ); ${ }^{1} \mathrm{H}-\mathrm{NMR}\left(300 \mathrm{MHz}, \mathrm{CDCl}_{3}\right) \square 0.03(\mathrm{~s}, 9 \mathrm{H}), 0.98(\mathrm{t}, J=8.3 \mathrm{~Hz}, 2 \mathrm{H}), 0.98-1.10(\mathrm{~m}, 1 \mathrm{H}), 1.16(\mathrm{~s}, 3 \mathrm{H})$, 1.43 (dddd, $J=12.7,12.7,12.7,3.4 \mathrm{~Hz}, 1 \mathrm{H}), 1.63-1.89(\mathrm{~m}, 4 \mathrm{H}), 1.85(\mathrm{~s}, 3 \mathrm{H}), 2.09$ (m, 1H), 2.15 (d, $J=2.4 \mathrm{~Hz}$, $1 \mathrm{H}), 2.30$ (broad s, 1H), $2.46(\mathrm{~s}, 3 \mathrm{H}), 2.82$ (broad s, 1H), $3.30(\mathrm{dd}, J=9.5,9.5 \mathrm{~Hz}, 1 \mathrm{H}), 3.74(\mathrm{~m}, 2 \mathrm{H}), 4.03(\mathrm{dd}$, $J=9.8,2.9 \mathrm{~Hz}, 1 \mathrm{H}), 4.31(\mathrm{dd}, J=9.8,4.7 \mathrm{~Hz}, 1 \mathrm{H}), 5.31,5.34(2 \mathrm{~d}, J=5.3 \mathrm{~Hz}, 1 \mathrm{H} \square 2), 5.75(\mathrm{~s}, 1 \mathrm{H}), 7.36,7.80$ $(2 \mathrm{~d}, J=8.3 \mathrm{~Hz}, 2 \mathrm{H} \square 2) ;{ }^{13} \mathrm{C}-\mathrm{NMR}\left(75 \mathrm{MHz}, \mathrm{CDCl}_{3}\right) \square \square 1.45 \square 3,15.97,17.98,21.63,22.52,26.15,27.03,37.47$,

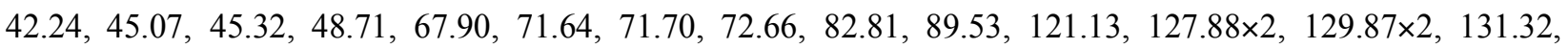
132.78, 144.86, 173.91; IR (neat) 3540, 3300, 3280, 2950, 2925, 2890, 2110, 1730, 1715, 1600, $1455 \mathrm{~cm}^{\square}$; HRMS calcd for $\mathrm{C}_{29} \mathrm{H}_{43} \mathrm{O}_{7} \mathrm{SiS}\left(\mathrm{M}^{+}+\mathrm{H}\right) \mathrm{m} / \mathrm{z}$ 563.2499, found 563.2484.

\section{2-(Trimethylsilyl)ethoxymethyl $(1 R, 2 S, 4 \mathrm{a} R, 5 R, 6 S, 8 \mathrm{a} S)$-2-ethynyl-5-hydroxy-1,3,6-trimethyl-1,2,4a,5,6,7, 8,8a-octahydronaphthalene-1-carboxylate (23)}

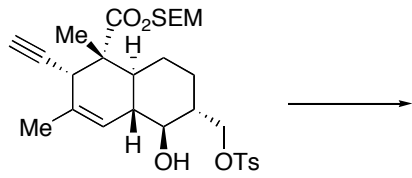

22

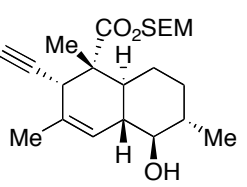

23

The following reaction was carried out under argon. To a heated $\left(100{ }^{\circ} \mathrm{C}\right)$, stirred solution of $22(144 \mathrm{mg}$, $0.255 \mathrm{mmol})$ in DMSO $(13 \mathrm{~mL})$ was added a solution of $\mathrm{NaBH}_{4}(38.6 \mathrm{mg}, 1.02 \mathrm{mmol})$ in DMSO $(3 \mathrm{~mL})$. The mixture was stirred at $100{ }^{\circ} \mathrm{C}$ for $15 \mathrm{~min}$. After being cooled to ambient temperature, the mixture was diluted with cooled $\mathrm{H}_{2} \mathrm{O}(60 \mathrm{~mL})$ and saturated brine $(10 \mathrm{~mL})$. This was extracted with $\mathrm{Et}_{2} \mathrm{O}(35 \mathrm{~mL} \square 3)$. The combined organic layers were washed with $\mathrm{H}_{2} \mathrm{O}(10 \mathrm{~mL} \square 3)$. The organic layer was dried and concentrated in vacuo. The residue was purified by column chromatography on silica gel (EtOAc/hexane, 1:10) to provide 82.1 $\mathrm{mg}(82 \%)$ of 23 as a colorless oil; TLC, $\mathrm{R}_{f} 0.58$ (EtOAc/hexane, 1:2); [ []$^{23.0}{ }_{\mathrm{D}}+121\left(c 0.88, \mathrm{CHCl}_{3}\right) ;{ }^{1} \mathrm{H}-\mathrm{NMR}$ $\left(300 \mathrm{MHz}, \mathrm{CDCl}_{3}\right) \square 0.03(\mathrm{~s}, 9 \mathrm{H}), 0.97(\mathrm{t}, J=8.4 \mathrm{~Hz}, 2 \mathrm{H}), 1.00-1.31(\mathrm{~m}, 2 \mathrm{H}), 1.04(\mathrm{~d}, J=6.4 \mathrm{~Hz}, 3 \mathrm{H}), 1.18$ (s, $3 \mathrm{H}), 1.40-1.47(\mathrm{~m}, 1 \mathrm{H}), 1.67-1.93(\mathrm{~m}, 3 \mathrm{H}), 1.85(\mathrm{~s}, 3 \mathrm{H}), 2.01(\mathrm{~m}, 1 \mathrm{H}), 2.14(\mathrm{~d}, J=2.4 \mathrm{~Hz}, 1 \mathrm{H}), 2.82$ (broad s, $1 \mathrm{H}), 2.98(\mathrm{dd}, J=9.5,9.5 \mathrm{~Hz}, 1 \mathrm{H}), 3.75(\mathrm{~m}, 2 \mathrm{H}), 5.31,5.36(2 \mathrm{~d}, J=6.1 \mathrm{~Hz}, 1 \mathrm{H} \square 2), 5.81(\mathrm{~s}, 1 \mathrm{H}) ;{ }^{13} \mathrm{C}-\mathrm{NMR}(75$ $\left.\mathrm{MHz}, \mathrm{CDCl}_{3}\right) \square \square 1.45 \square 3,16.05,18.01,18.59,22.53,26.83,33.03,37.98,40.81,42.27,45.37,48.85,67.87$, 71.41, 78.84, 83.12, 89.52, 121.92, 130.76, 174.12; IR (neat) 3310, 3280, 2950, 2920, 2890, 2110, 1740, 1730, $1460,1455 \mathrm{~cm}^{\square}$; HRMS calcd for $\mathrm{C}_{22} \mathrm{H}_{36} \mathrm{O}_{4} \mathrm{Si}\left(\mathrm{M}^{+}\right) \mathrm{m} / \mathrm{z} 392.2383$, found 392.2381 .

2-(Trimethylsilyl)ethoxymethyl $(1 R, 2 S, 4 \mathrm{a} R, 5 R, 6 S, 8 \mathrm{a} S)$-5-hydroxy-2-[(E)-2-iodoethenyl]-1,3,6-trimethyl$1,2,4 a, 5,6,7,8,8$ a-octahydronaphthalene-1-carboxylate (3)
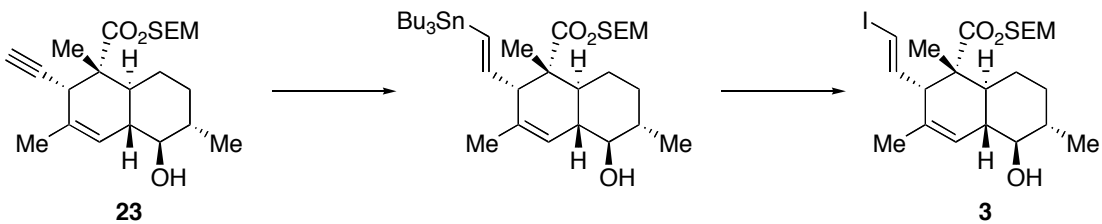

The following reaction was carried out under argon. To a stirred solution of 23 (111 $\mathrm{mg}, 0.282 \mathrm{mmol})$ in THF $(2.2 \mathrm{~mL})$ were added $\mathrm{Pd}\left(\mathrm{PPh}_{3}\right)_{2} \mathrm{Cl}_{2}(19.8 \mathrm{mg}, 28.2 \square \mathrm{mol})$ and $\mathrm{Bu}_{3} \mathrm{SnH}(0.15 \mathrm{~mL}, 0.56 \mathrm{mmol})$. The reaction mixture was stirred for $10 \mathrm{~min}$ and then concentrated in vacuo. The residue was purified by column chromatography on silica gel (doped with $\left.\mathrm{Et}_{3} \mathrm{~N}, \mathrm{EtOAc} / \mathrm{hexane}, 1: 15\right)$ to provide $165 \mathrm{mg}$ of vinylstannanes as a 
colorless oil. This material was dissolved in $\mathrm{CH}_{2} \mathrm{Cl}_{2}(3.3 \mathrm{~mL})$ and stirred at $0{ }^{\circ} \mathrm{C}$. To the solution $\mathrm{I}_{2}(61.2 \mathrm{mg}$, $0.241 \mathrm{mmol}$ ) was added. The mixture was stirred at $0{ }^{\circ} \mathrm{C}$ for $1 \mathrm{~h}$ and warmed to ambient temperature for $1 \mathrm{~h}$. The mixture was diluted with $20 \%$ aqueous $\mathrm{Na}_{2} \mathrm{~S}_{2} \mathrm{O}_{3}(15 \mathrm{~mL})$ at $0{ }^{\circ} \mathrm{C}$. This was stirred for $5 \mathrm{~min}$ and extracted with $\mathrm{CH}_{2} \mathrm{Cl}_{2}(7 \mathrm{~mL} \square 3)$. The combined organic layers were dried and concentrated in vacuo. The residue was purified by column chromatography on silica gel (doped with $\mathrm{Et}_{3} \mathrm{~N}$, EtOAc/hexane, 1:15) to provide $109 \mathrm{mg}$ (74\%, 2 steps) of 3 as a colorless oil; TLC, $\mathrm{R}_{f} 0.58$ (EtOAc/hexane, 1:2); [ $]^{24.5}{ }_{\mathrm{D}}+194\left(c 1.61 \mathrm{CHCl}_{3}\right) ;{ }^{1} \mathrm{H}-$ NMR (300 MHz, CDCl $) \square 0.04(\mathrm{~s}, 9 \mathrm{H}), 0.99$ (t, $J=8.3 \mathrm{~Hz}, 2 \mathrm{H}), 1.05(\mathrm{~d}, J=6.3 \mathrm{~Hz}, 3 \mathrm{H}), 1.10-1.21(\mathrm{~m}, 2 \mathrm{H})$, $1.16(\mathrm{~s}, 3 \mathrm{H}), 1.37-1.47(\mathrm{~m}, 1 \mathrm{H}), 1.65(\mathrm{~s}, 3 \mathrm{H}), 1.69-1.72(\mathrm{~m}, 3 \mathrm{H}), 1.78-1.81(\mathrm{~m}, 1 \mathrm{H}), 2.40(\mathrm{~d}, J=10.0 \mathrm{~Hz}, 1 \mathrm{H})$, $2.92(\mathrm{dd}, J=9.0,9.0 \mathrm{~Hz}, 1 \mathrm{H}), 3.72(\mathrm{t}, J=8.3 \mathrm{~Hz}, 2 \mathrm{H}), 5.15,5.36(2 \mathrm{~d}, J=6.1 \mathrm{~Hz}, 1 \mathrm{H} \square 2), 5.84(\mathrm{~s}, 1 \mathrm{H}), 6.03(\mathrm{~d}$, $J=14.4 \mathrm{~Hz}, 1 \mathrm{H}), 6.33(\mathrm{dd}, J=14.4,10.0 \mathrm{~Hz}, 1 \mathrm{H}) ;{ }^{13} \mathrm{C}-\mathrm{NMR}\left(68 \mathrm{MHz}, \mathrm{CDCl}_{3}\right) \square \square 1.39 \square 3,16.35,18.11,18.60$, 22.46, 26.92, 33.17, 37.81, 40.80, 45.32, 49.21, 57.56, 68.16, 76.42, 79.19, 89.82, 122.38, 130.99, 145.54, 174.59; IR (neat) $3340,2950,2920,1730,1710,1595,1455 \mathrm{~cm}^{\square}$; HRMS calcd for $\mathrm{C}_{22} \mathrm{H}_{35} \mathrm{O}_{3} \mathrm{SiI}\left(\mathrm{M}^{+} \square \mathrm{H}_{2} \mathrm{O}\right)$ $\mathrm{m} / \mathrm{z}$ 502.1401, found 502.1400. 